\title{
Article
}

\section{The Interaction of Selective A1 and A2A Adenosine Receptor Antagonists with Magnesium and Zinc Ions in Mice: Behavioural, Biochemical and Molecular Studies}

\author{
Aleksandra Szopa ${ }^{1, *(D)}$, Karolina Bogatko ${ }^{1}$, Mariola Herbet ${ }^{2} \mathbb{D}$, Anna Serefko ${ }^{1}$ (D), Marta Ostrowska ${ }^{2}$, \\ Sylwia Wośko ${ }^{1}$, Katarzyna Świąder ${ }^{3}$, Bernadeta Szewczyk ${ }^{4}$, Aleksandra Wlaź ${ }^{5}$, Piotr Skałecki ${ }^{6}$, \\ Andrzej Wróbel ${ }^{7}$ (D), Sławomir Mandziuk ${ }^{8}$, Aleksandra Pochodyła ${ }^{3}$, Anna Kudela ${ }^{2}$, Jarosław Dudka ${ }^{2}$, \\ Maria Radziwoń-Zaleska ${ }^{9}$, Piotr Wlaź ${ }^{10}$ and Ewa Poleszak ${ }^{1, * \mathbb{D}}$
}

Citation: Szopa, A.; Bogatko, K.; Herbet, M.; Serefko, A.; Ostrowska, M.; Wośko, S.; Świąder, K.; Szewczyk, B.; Wlaź, A.; Skałecki, P.; et al. The Interaction of Selective $\mathrm{A} 1$ and $\mathrm{A} 2 \mathrm{~A}$ adenosine Receptor Antagonists with Magnesium and Zinc Ions in Mice: Behavioural, Biochemical and Molecular Studies. Int. J. Mol. Sci. 2021, 22, 1840. https://doi.org/ $10.3390 /$ ijms 22041840

Academic Editor: Elek Molnár

Received: 26 January 2021

Accepted: 10 February 2021

Published: 12 February 2021

Publisher's Note: MDPI stays neutral with regard to jurisdictional claims in published maps and institutional affiliations.

Copyright: (c) 2021 by the authors. Licensee MDPI, Basel, Switzerland. This article is an open access article distributed under the terms and conditions of the Creative Commons Attribution (CC BY) license (https:/ / creativecommons.org/licenses/by/ $4.0 /)$.
1 Chair and Department of Applied and Social Pharmacy, Laboratory of Preclinical Testing, Medical University of Lublin, 1 Chodźki Street, PL 20-093 Lublin, Poland; karolina.bogatko@umlub.pl (K.B.); anna.serefko@umlub.pl (A.S.); sylwia.wosko@umlub.pl (S.W.)

2 Chair and Department of Toxicology, Medical University of Lublin, 8 Chodźki Street, PL 20-093 Lublin, Poland; mariola.herbet@umlub.pl (M.H.); marta.ostrowska@umlub.pl (M.O.); ankaku@poczta.onet.pl (A.K.) jaroslaw.dudka@umlub.pl (J.D.)

3 Chair and Department of Applied and Social Pharmacy, Medical University of Lublin, 1 Chodźki Street, PL 20-093 Lublin, Poland; katarzyna.swiader@umlub.pl (K.Ś.); olaap@onet.pl (A.P.)

4 Department of Neurobiology, Polish Academy of Sciences, Maj Institute of Pharmacology, 12 Smętna Street, PL 31-343 Kraków, Poland; szewczyk@if-pan.krakow.pl

5 Department of Pathophysiology, Medical University of Lublin, 8 Jaczewskiego Street, PL 20-090 Lublin, Poland; aleksandra.wlaz@umlub.pl

6 Department of Commodity Science and Processing of Raw Animal Materials, University of Life Sciences, 13 Akademicka Street, PL 20-950 Lublin, Poland; piotr.skalecki@up.lublin.pl

7 Second Department of Gynecology, 8 Jaczewskiego Street, PL 20-090 Lublin, Poland; wrobelandrzej@yahoo.com

8 Department of Pneumology, Oncology and Allergology, Medical University of Lublin, 8 Jaczewskiego Street, PL 20-090 Lublin, Poland; slawomir.mandziuk@umlub.pl

9 Department of Psychiatry, Medical University of Warsaw, 27 Nowowiejska Street, PL 00-665 Warsaw, Poland; maria.radziwon@wum.edu.pl

10 Department of Animal Physiology and Pharmacology, Institute of Biological Sciences, Maria Curie-Skłodowska University, Akademicka 19, PL 20-033 Lublin, Poland; piotr.wlaz@umcs.lublin.pl

* Correspondence: aleksandra.szopa@umlub.pl (A.S.); ewa.poleszak@umlub.pl (E.P.)

Abstract: The purpose of the study was to investigate whether the co-administration of $\mathrm{Mg}^{2+}$ and $\mathrm{Zn}^{2+}$ with selective $\mathrm{A} 1$ and $\mathrm{A} 2 \mathrm{~A}$ receptor antagonists might be an interesting antidepressant strategy. Forced swim, tail suspension, and spontaneous locomotor motility tests in mice were performed. Further, biochemical and molecular studies were conducted. The obtained results indicate the interaction of DPCPX and istradefylline with $\mathrm{Mg}^{2+}$ and $\mathrm{Zn}^{2+}$ manifested in an antidepressant-like effect. The reduction of the BDNF serum level after co-administration of DPCPX and istradefylline with $\mathrm{Mg}^{2+}$ and $\mathrm{Zn}^{2+}$ was noted. Additionally, $\mathrm{Mg}^{2+}$ or $\mathrm{Zn}^{2+}$, both alone and in combination with DPCPX or istradefylline, causes changes in Adora1 expression, DPCPX or istradefylline co-administered with $\mathrm{Zn}^{2+}$ increases Slc6a15 expression as compared to a single-drug treatment, co-administration of tested agents does not have a more favourable effect on Comt expression. Moreover, the changes obtained in Ogg1, MsrA, Nrf2 expression show that DPCPX-Mg ${ }^{2+}, \mathrm{DPCPX}-\mathrm{Zn}^{2+}$, istradefylline- $\mathrm{Mg}^{2+}$ and istradefylline- $\mathrm{Zn}^{2+}$ co-treatment may have greater antioxidant capacity benefits than administration of DPCPX and istradefylline alone. It seems plausible that a combination of selective A1 as well as an A2A receptor antagonist and magnesium or zinc may be a new antidepressant therapeutic strategy.

Keywords: DPCPX; istradefylline; magnesium; zinc; antidepressant activity 


\section{Introduction}

The magnesium ion $\left(\mathrm{Mg}^{2+}\right)$, a fundamental intracellular cation, and the zinc ion $\left(\mathrm{Zn}^{2+}\right)$, the second most abundant trace element in the human body, are indispensable for the proper course of various physiological processes [1,2], including the central nervous system (CNS) functioning and development $[1,3]$. Both preclinical and clinical research conducted over recent years have provided a great deal of evidence for the involvement of $\mathrm{Mg}^{2+}$ and $\mathrm{Zn}^{2+}$ in the etiopathogenesis and therapy of depressive disorders. It is mainly related to disturbances of glutamatergic transmission in brain structures that play a key role in the pathophysiology of depression [4-8]. Additionally, magnesium and zinc enhance the activity of antidepressant agents (e.g., imipramine, fluoxetine, paroxetine, citalopram, tianeptine and bupropion) [4,5,9-12].

Currently, the best documented mechanism of antidepressant-like activity of magnesium ions seems to be their inhibitory effect on glutamatergic transmission through antagonism of $N$-methyl-D -aspartic (NMDA) receptor complex [13]. It was shown that the antidepressant activity of magnesium recorded in the forced swim test (FST) was antagonized by NMDA receptor agonist (NMDA or D-serine) co-administration [14] Moreover, Poleszak et al. [14] demonstrated that $\mathrm{Mg}^{2+}$ potentiates the antidepressant-like activity of NMDA receptor complex antagonists (L-701,324, CGP 37849, dizocilpine, Dcycloserine) in a mouse despair test when used jointly at non-active doses. The leading mechanism of $\mathrm{Zn}^{2+}$ action, similarly to $\mathrm{Mg}^{2+}$, is its effect on the activity of the NMDA receptor complex. Synaptic zinc modulates also activity of other ionotropic glutamate receptors, i.e., $\alpha$-amino-3-hydroxy-5-methyl-4-isoxazole-propionic acid (AMPA) receptors, as well as metabotropic glutamate receptors, mGluR. Moreover, $\mathrm{Zn}^{2+}$ affects functions of $\gamma$-aminobutyric acid (GABA-A), glycine inotropic as well as GPR39 metabotropic receptors (a specific $\mathrm{Zn}^{2+}$-susceptible receptor) [13]. In the literature two distinct zinc mechanisms of NMDA receptor complex inhibition have been described: a non-competitive and voltageindependent antagonism, as a result of which the opening frequency of the receptor channel is decreased, and voltage-dependent antagonism contributing to blocking the receptor channel opening [15-17].

Adenosine is a significant endogenous neuromodulator in the CNS [18]. Adenosine receptors play pivotal role in mediating adenosine transduction $[19,20]$. Regarding biochemical, pharmacological, structural functions and properties, four subtypes of adenosine receptors have been distinguished, i.e., A1, A2A, A2B and A3 [19]. Among them, A1 and A2A receptors are the most abundant in the brain. The A1 receptor is coupled to $G_{i / o}$ protein and is distributed all over the CNS (i.e., cerebral cortex, hippocampus, striatum, thalamic, cerebellum, the dorsal part of the spinal cord). Its stimulation entails inhibition of adenylate cyclase and $\mathrm{Ca}^{2+}$ channels, but activation of $\mathrm{K}^{+}$channels [21]. Instead, the A2A receptor is coupled to $G_{s}$ protein and enhances the adenylate cyclase activity. This subtype of adenosine receptors is mostly localized in the dorsal striato-pallidal GABA pathway and also in the nucleus accumbens, cerebral cortex and hippocampus $[18,19]$. Furthermore, in the striatal glutamate nerve terminals at the presynaptic level A1-A2A heterotertameric receptor complexes were recognized [20,22].

A growing body of evidence indicate the interaction between the glutamatergic and adenosine system, and there are several possible mechanisms of association between these systems. Firstly, by stimulating the A1 and A2A receptors, adenosine modulates the release of several neurotransmitters, including glutamate [23]. Additionally, adenosine by antagonizing membrane depolarization elevates the threshold needed to open the NMDA receptor channels [24]. Moreover, it has been shown that relationship between NMDA and A1 receptors leads to down-regulation of presynaptic glutamate release in neurons of the cingulate cortex [25], hippocampus [26] and striatum [27]. It was also presented that elevate extracellular concentration of adenosine could induce the A2A receptor protomer in the A1-A2A heteroreceptor complex exhibiting an antagonistic allosteric receptor-receptor interaction restricting A1 receptor protomer signalling. This receptor complex is localized on the striatal glutamate nerve terminals and the reduction of the inhibitory A1 receptor 
protomer signalling causes enhancement in glutamate release [28]. However, to the best of authors' knowledge, the interaction between selective adenosine A1 or A2A receptor antagonists and ionic NMDA receptor antagonists in behavioural tests in rodents has not been studied hitherto. Since the antidepressant effect of $\mathrm{Mg}^{2+}$ and $\mathrm{Zn}^{2+}$ ions $[9,10]$ and both non-selective $[29,30]$ and selective [31-33] antagonists of the adenosine receptors in mice despair tests have been proven, we decided to examine whether the co-administration of magnesium and zinc hydroaspartate with the selective $\mathrm{A} 1$ or $\mathrm{A} 2 \mathrm{~A}$ receptor antagonist (DPCPX and istradefylline, respectively) might be an interesting strategy in the context of depression therapy. To this end, we have performed behavioural tests (FST, tail suspension test (TST) and spontaneous locomotor motility test) as well as biochemical and molecular studies in which we evaluated: (1) The serum level of brain-derived neurotrophic factor (BDNF), which is common neurotrophic factors in adult humans and animals and is acknowledged as one of the biomarkers of depression, and (2) the expression of selected genes that may play a role in the pathophysiology and treatment of depression or the mechanism of adenosine A1 and A2A antagonists action (i.e., Adora1, Slc6a15, Comt), and (3) the expression of selected antioxidant defence genes (i.e., Ogg1, MsrA, Nrf2) since oxidative stress plays an important role in the aetiology of depression.

\section{Results}

\subsection{Behavioural Studies}

2.1.1. Effect of Co-Administration of Selective Adenosine Receptor Antagonists and Magnesium or Zinc in the FST

\section{(1) DPCPX and Magnesium or Zinc}

As shown in Figure 1A neither DPCPX $(1 \mathrm{mg} / \mathrm{kg})$ nor $\mathrm{Mg}^{2+}(10 \mathrm{mg} / \mathrm{kg})$ nor $\mathrm{Zn}^{2+}$ $(2.5 \mathrm{mg} / \mathrm{kg})$ caused statistically significant changes in the FST $(p>0.05)$.

DPCPX and $\mathrm{Mg}^{2+}$ injected simultaneously at non-effective doses (1 and $10 \mathrm{mg} / \mathrm{kg}$, respectively) caused a significant decrease in total immobility time in comparison to $\mathrm{NaCl}$, DPCPX- and $\mathrm{Mg}^{2+}$-treated group ( $p<0.05, p<0.01$ and $p<0.01$, respectively). A two-way ANOVA showed a significant interaction between DPCPX and $\mathrm{Mg}^{2+}[\mathrm{F}(1,35)=6.61, p=0.0145]$.

DPCPX and $\mathrm{Zn}^{2+}$ injected simultaneously at non-effective doses $(1$ and $2.5 \mathrm{mg} / \mathrm{kg}$, respectively) caused a significant decrease in total immobility time in comparison to DPCPX- and $\mathrm{Zn}^{2+}$-treated group $(p<0.05)$. A two-way ANOVA showed a significant interaction between DPCPX and $\mathrm{Zn}^{2+}[\mathrm{F}(1,35)=6.45, p=0.0157]$.

(2) Istradefylline and Magnesium or Zinc

As shown in Figure 1A neither istradefylline $(0.5 \mathrm{mg} / \mathrm{kg})$ nor $\mathrm{Mg}^{2+}(10 \mathrm{mg} / \mathrm{kg})$ nor $\mathrm{Zn}^{2+}(2.5 \mathrm{mg} / \mathrm{kg})$ caused statistically significant changes in the FST $(p>0.05)$.

Istradedylline and $\mathrm{Mg}^{2+}$ injected simultaneously at non-effective doses (0.5 and $10 \mathrm{mg} / \mathrm{kg}$, respectively) caused a significant decrease in total immobility time in comparison to $\mathrm{NaCl}$-, istradefylline- and $\mathrm{Mg}^{2+}$-treated group $(p<0.0001)$. A two-way ANOVA showed a significant interaction between istradefylline and $\mathrm{Mg}^{2+}[\mathrm{F}(1,36)=20.76, p<0.0001]$.

Istradefylline and $\mathrm{Zn}^{2+}$ injected simultaneously at non-effective doses $(0.5$ and $2.5 \mathrm{mg} / \mathrm{kg}$, respectively) caused a significant decrease in total immobility time in comparison to $\mathrm{NaCl}$, istradefylline- and $\mathrm{Zn}^{2+}$-treated group $(p<0.0001)$. A two-way ANOVA showed a significant interaction between istradefylline and $\mathrm{Zn}^{2+}[\mathrm{F}(1,36)=18.78, p=0.0001]$. 
A

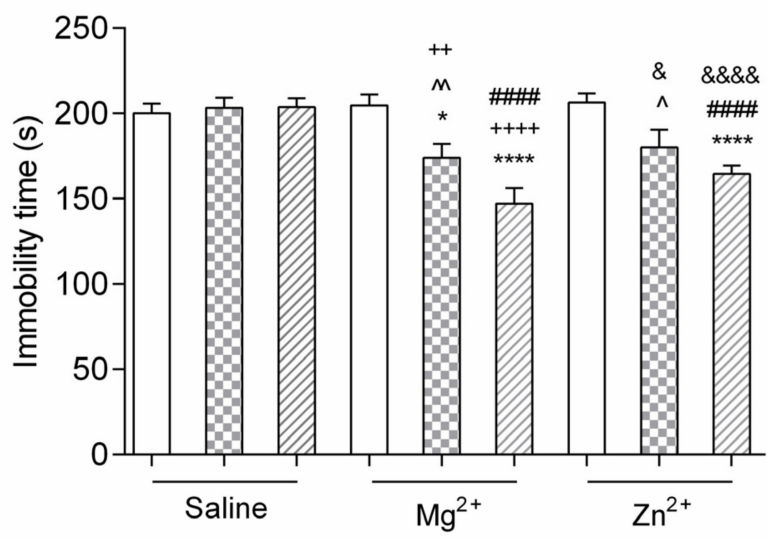

B

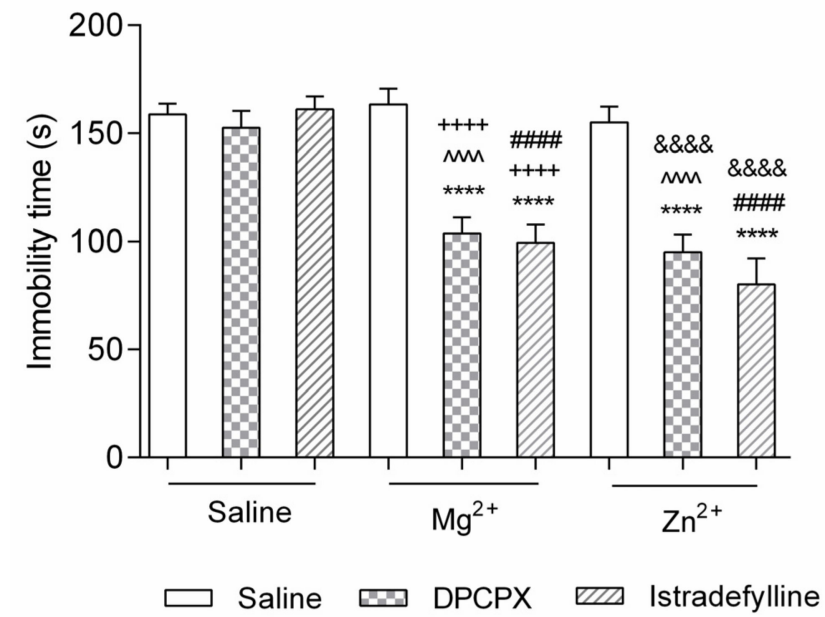

Figure 1. Effect of co-administration of DPCPX and istradefylline with $\mathrm{Mg}^{2+}$ and $\mathrm{Zn}^{2+}$ in the (A) FST and (B) TST in mice. DPCPX, $\mathrm{Mg}^{2+}$ and saline were administered i.p. $30 \mathrm{~min}$, whereas istradefylline p.o. and $\mathrm{Zn}^{2+}$ i.p. $60 \mathrm{~min}$ prior behavioural testing. The data are presented as the means $\pm \mathrm{SEM}$. Each experimental group consisted of 10 animals. (A) ${ }^{*} p<0.05,{ }^{* * *} p<0.0001$ vs. NaCl-treated group; ${ }^{\wedge} p<0.05,{ }^{\wedge} p<0.01$ vs. DPCPX-treated group; \#\#\# $p<0.0001$ vs. istradefylline-treated group; ${ }^{++} p<0.01$ vs. $\mathrm{Mg}^{2+}$-treated group; \& $p<0.05, \& \& \& \& p<0.0001$ vs. $\mathrm{Zn}^{2+}$-treated group (two-way ANOVA followed by Bonferroni's post hoc test); (B) ${ }^{* * *} p<0.0001$ vs. NaCl-treated group; ${ }^{\wedge \wedge} p<0.0001$ vs. DPCPX-treated group; \#\#\# $p<0.0001$ vs. istradefylline-treated group; ${ }^{++++} p<0.0001$ vs. $\mathrm{Mg}^{2+}$-treated group; \&\&\&\& $p<0.0001$ vs. $\mathrm{Zn}^{2+}$-treated group (two-way ANOVA followed by Bonferroni's post hoc test)

2.1.2. Effect of Co-Administration of Selective Adenosine Receptor Antagonists and Magnesium in the TST

(1) DPCPX and Magnesium or Zinc

As shown in Figure 1B neither DPCPX $(1 \mathrm{mg} / \mathrm{kg})$ nor $\mathrm{Mg}^{2+}(10 \mathrm{mg} / \mathrm{kg})$ nor $\mathrm{Zn}^{2+}$ $(2.5 \mathrm{mg} / \mathrm{kg})$ caused statistically significant changes in the TST $(p>0.05)$.

DPCPX and $\mathrm{Mg}^{2+}$ injected simultaneously at non-effective doses $(1$ and $10 \mathrm{mg} / \mathrm{kg}$, respectively) caused a significant decrease in total immobility time in comparison to $\mathrm{NaCl}$, 
DPCPX- and $\mathrm{Mg}^{2+}$-treated group $(p<0.0001)$. A two-way ANOVA showed a significant interaction between DPCPX and $\mathrm{Mg}^{2+}[\mathrm{F}(1,36)=14.73, p=0.0005]$.

DPCPX and $\mathrm{Zn}^{2+}$ injected simultaneously at non-effective doses $(1$ and $2.5 \mathrm{mg} / \mathrm{kg}$, respectively) caused a significant decrease in total immobility time in comparison to $\mathrm{NaCl}$-, DPCPX- and $\mathrm{Zn}^{2+}$-treated group $(p<0.0001)$. A two-way ANOVA showed a significant interaction between DPCPX and $\mathrm{Zn}^{2+}[\mathrm{F}(1,36)=13.76, p=0.0007]$.

(2) Istradefylline and Magnesium or Zinc

As shown in Figure 1B neither istradefillyne $(0.5 \mathrm{mg} / \mathrm{kg})$ nor $\mathrm{Mg}^{2+}(10 \mathrm{mg} / \mathrm{kg})$ nor $\mathrm{Zn}^{2+}(2.5 \mathrm{mg} / \mathrm{kg})$ caused statistically significant changes in the FST $(p>0.05)$.

Istradefylline and $\mathrm{Mg}^{2+}$ injected simultaneously at non-effective doses $(0.5$ and $10 \mathrm{mg} / \mathrm{kg}$, respectively) caused a significant decrease in total immobility time in comparison to $\mathrm{NaCl}$, istradefylline- and $\mathrm{Mg}^{2+}$-treated group $(p<0.0001)$. A two-way ANOVA showed a significant interaction between istradefylline and $\mathrm{Mg}^{2+}[\mathrm{F}(1,36)=23.98, p<0.0001]$.

Istradefylline and $\mathrm{Zn}^{2+}$ injected simultaneously at non-effective doses $(0.5$ and $2.5 \mathrm{mg} / \mathrm{kg}$, respectively) caused a significant decrease in total immobility time in comparison to $\mathrm{NaCl}$, istradefylline- and $\mathrm{Zn}^{2+}$-treated group $(p<0.0001)$. A two-way ANOVA showed a significant interaction between istradefylline and $\mathrm{Zn}^{2+}[\mathrm{F}(1,36)=22.46, p<0.0001]$.

\subsubsection{Spontaneous Locomotor Motility}

The effect of DPCPX (1 mg/ $\mathrm{kg})$, istradefylline $(0.5 \mathrm{mg} / \mathrm{kg}), \mathrm{Mg}^{2+}(10 \mathrm{mg} / \mathrm{kg}), \mathrm{Zn}^{2+}$ $(2.5 \mathrm{mg} / \mathrm{kg})$ and co-administration of $\mathrm{Mg}^{2+}$ or $\mathrm{Zn}^{2+}$ with DPCPX or istradefylline on spontaneous locomotor motility in mice is shown in Table 1. DPCPX, istradefylline, and $\mathrm{Mg}^{2+}$ given alone or in combination had no statistically significant effects on locomotor motility in mice $(p>0.05) . \mathrm{Zn}^{2+}$ administered alone and in combination with DPCPX significantly decreases the distance travelled by mice $(p<0.05$ and $p<0.001$ in comparison to $\mathrm{NaCl}$-treated group, respectively).

Table 1. Effect of treatments on mice spontaneous motility.

\begin{tabular}{cc}
\hline Treatment $(\mathbf{m g} / \mathbf{k g})$ & $\begin{array}{c}\text { Distance }(\mathbf{c m}) \text { between the 2nd and } \\
\text { the 6th Minute }\end{array}$ \\
\hline saline + saline & $1196.5 \pm 58.3$ \\
DPCPX 1 + saline & $1111.8 \pm 57.1$ \\
istradefylline $0.5+$ saline & $1093.2 \pm 54.7$ \\
$\mathrm{Mg}^{2+} 10+$ saline & $1028.9 \pm 73.2$ \\
DPCPX $1+\mathrm{Mg}^{2+} 10$ & $905.40 \pm 93.5$ \\
istradefylline $0.5+\mathrm{Mg}^{2+} 10$ & $1150.9 \pm 37.3$ \\
$\mathrm{Zn}{ }^{2+} 2.5+$ saline & $986.90 \pm 38.2 *$ \\
DPCPX $1+\mathrm{Zn}^{2+} 2.5$ & $766.40 \pm 89.7 * * *, \wedge \cdots, \&$ \\
istradefylline $0.5+\mathrm{Zn}^{2+} 2.5$ & $1186.8 \pm 90.9$ \\
\hline
\end{tabular}

DPCPX, $\mathrm{Mg}^{2+}$ and saline were administered i.p. $30 \mathrm{~min}$, whereas istradefylline p.o. and $\mathrm{Zn}^{2+}$ i.p. 60 min prior spontaneous motility test. Distance travelled was recorded between the 2nd and the 6th min of the test. Each experimental group consisted of 9-10 animals. Data are presented as the means \pm SEM. ${ }^{*} p<0.05,{ }^{* * *} p<0.001$ vs. NaCl-treated group; ${ }^{\wedge} p<0.001$ vs. DPCPX-treated group; ${ }^{\&} p<0.05$ vs. $\mathrm{Zn}^{2+}$-treated group (two-way ANOVA followed by Bonferroni's post hoc test).

The two-way ANOVA demonstrated: (1) no interaction between DPCPX and $\mathrm{Mg}^{2+}$ $[\mathrm{F}(1,33)=0.08, p=0.7833],(2)$ no interaction between $\mathrm{DPCPX}$ and $\mathrm{Zn}^{2+}[\mathrm{F}(1,34)=0.17$, $p=0.6847]$, (3) no interaction between istradefylline and $\mathrm{Mg}^{2+}[\mathrm{F}(1,33)=3.94, p=0.0555]$, (4) a significant interaction between istradefylline and $\mathrm{Zn}^{2+}[\mathrm{F}(1,34)=5.25, p=0.0283]$.

\subsection{Biochemical and Molecular Studies}

2.2.1. Effect of Co-Administration of Selective Adenosine Receptor Antagonists and Magnesium or Zinc on BDNF Concentration

(1) DPCPX and Magnesium or Zinc 
As shown in Figure 2 neither DPCPX nor $\mathrm{Mg}^{2+}$ nor $\mathrm{Zn}^{2+}$ injected alone caused statistically significant changes in BDNF concentration $(p>0.05)$ as compared to the control group. Additionally, in the groups of animals that received DPCPX in a combination with $\mathrm{Zn}^{2+}$ no statistically significant changes in the concentration of BDNF were observed $(p>0.05)$. However, the co-administration of DPCPX with $\mathrm{Mg}^{2+}$ resulted in a significant decrease in BDNF level as compared to the control group $(p<0.0001)$ and to the group receiving DPCPX alone $(p<0.0001)$.

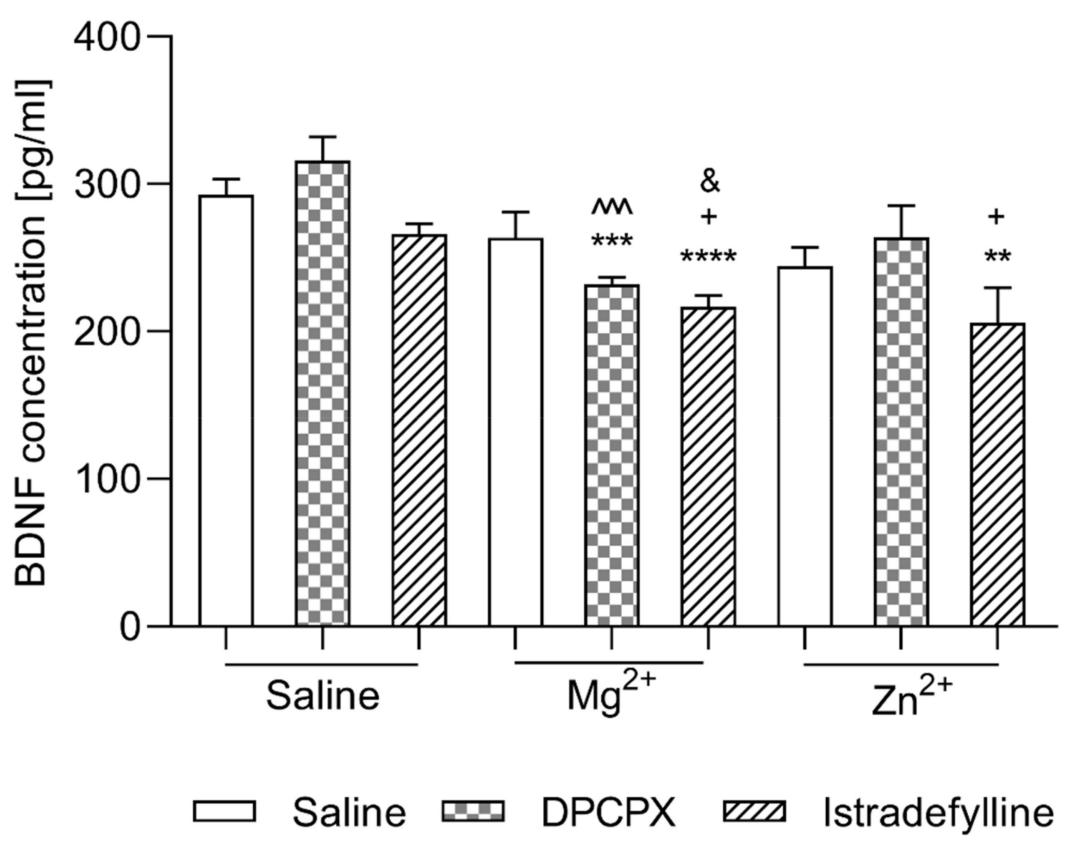

Figure 2. Effect of co-administration of DPCPX and istradefylline with $\mathrm{Mg}^{2+}$ and $\mathrm{Zn}^{2+}$ on $\mathrm{BDNF}$ concentration in mice serum. DPCPX, $\mathrm{Mg}^{2+}$ and saline were administered i.p. 30 min, whereas istradefylline p.o. and $\mathrm{Zn}^{2+}$ i.p. $60 \mathrm{~min}$ prior decapitation. The data are presented as the means \pm SEM. Each experimental group consisted of 10 animals. ${ }^{* *} p<0.01,{ }^{* * *} p<0.001,{ }^{* * * *} p<0.0001$ vs. NaCl-treated group; ${ }^{\wedge \uparrow} p<0.001$ vs. DPCPX- treated group; ${ }^{+} p<0.05$ vs. $\mathrm{Mg}^{2+}$-treated group; $\& p<0.05$ vs. $\mathrm{Zn}^{2+}$-treated group (two-way ANOVA followed by Bonferroni's post hoc test).

A two-way ANOVA showed no interaction between DPCPX and $\mathrm{Mg}^{2+}[\mathrm{F}(1,20)=4.20$, $p=0.0538]$ and no interaction between DPCPX and $\mathrm{Zn}^{2+}[\mathrm{F}(1,20)=0.01, p=0.9180]$.

(2) Istradefylline and Magnesium or Zinc

As shown in Figure 2 neither istradefylline nor $\mathrm{Mg}^{2+}$ nor $\mathrm{Zn}^{2+}$ caused statistically significant changes in BDNF concentration $(p>0.05)$ as compared to the control group. The co-administration of istradefylline with $\mathrm{Mg}^{2+}$ resulted in a significant decrease in BDNF level as compared to the control group $(p<0.0001)$ and to the group receiving istradefylline or $\mathrm{Mg}^{2+}$ alone $(p<0.05)$. Additionally, in the groups of animals that received istradefylline in combination with $\mathrm{Zn}^{2+}$, a statistically significant decrease in the BDNF concentration in comparison to the control group and to the group receiving istradefylline alone was observed ( $p<0.01$ and $p<0.05$, respectively).

A two-way ANOVA showed no interaction between istradefylline and $\mathrm{Mg}^{2+}[\mathrm{F}(1,20)=0.75$, $p=0.3959]$ and no interaction between istradefylline and $\mathrm{Zn}^{2+}[\mathrm{F}(1,20)=0.14, p=0.7086]$.

2.2.2. Effect of Co-Administration of Selective Adenosine Receptor Antagonists and Magnesium or Zinc on Adora1 Expression

(1) DPCPX and Magnesium or Zinc

As shown in Figure 3A DPCPX administered alone did not cause significant changes in the expression of Adora1. However, the single administration of $\mathrm{Mg}^{2+}$ or $\mathrm{Zn}^{2+}$ resulted 
in a significant increase in Adora1 mRNA level as compared to the control group $(p<0.01$ and $p<0.001$, respectively). Interestingly, DPCPX co-administered with $\mathrm{Mg}^{2+}$ caused a significant decrease in the Adora1 expression in comparison to the control group $(p<0.0001)$ and also to the DPCPX-treated group and to the group receiving $\mathrm{Mg}^{2+}$ alone $(p<0.0001)$. In turn, simultaneous treatment with DPCPX with $\mathrm{Zn}^{2+}$ resulted in a significant increase in Adora1 mRNA level as compared to the group that received DPCPX or $\mathrm{Zn}^{2+}(p<0.0001)$ alone.

A

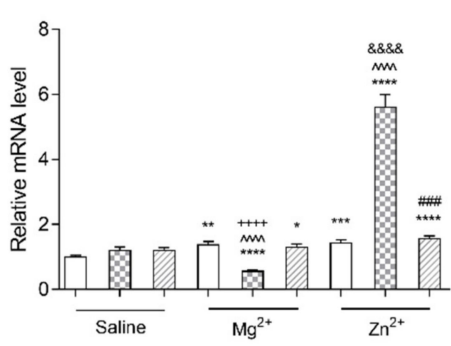

D

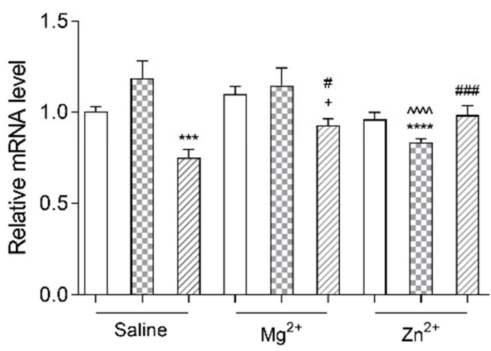

B
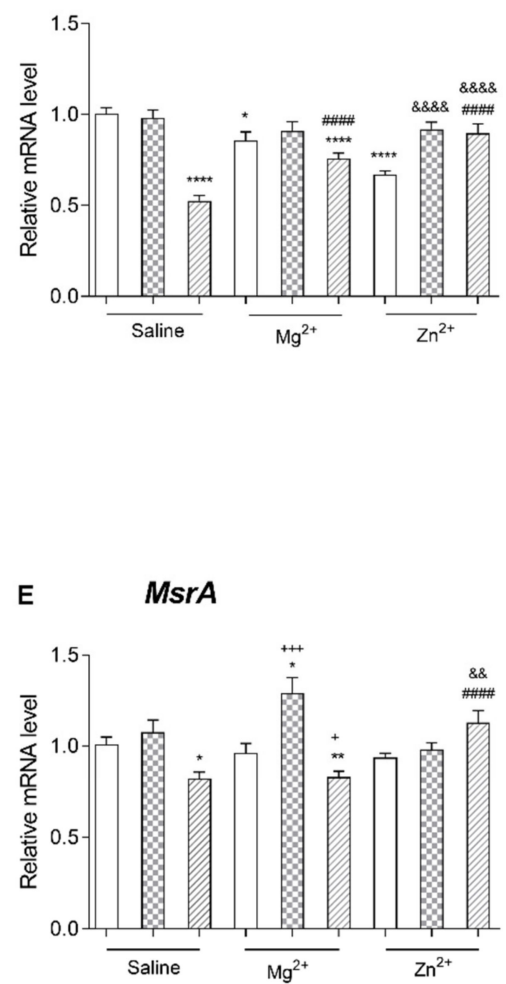

c

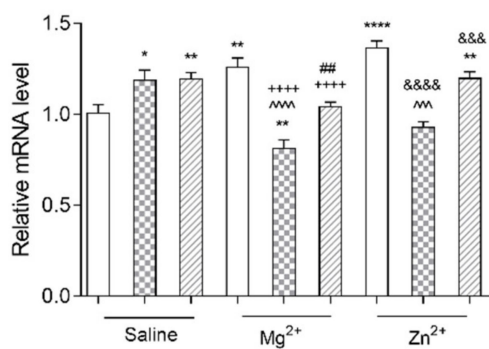

F $\quad$ Nrf2

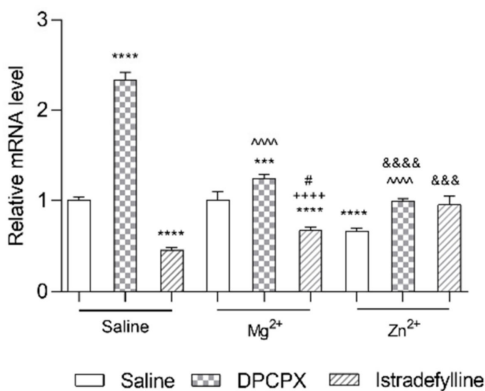

Figure 3. Effect of co-administration of DPCPX and istradefylline with $\mathrm{Mg}^{2+}$ and $\mathrm{Zn}^{2+}$ on gene expression (A) Adora1, (B) Slc6a15, (C) Comt, (D) Ogg1, (E) MsrA, and (F) Nrf2 in mice prefrontal cortex. DPCPX, $\mathrm{Mg}^{2+}$ and saline were administered i.p. $30 \mathrm{~min}$, whereas istradefylline p.o. and $\mathrm{Zn}^{2+}$ i.p. $60 \mathrm{~min}$ prior decapitation. The data are presented as the means \pm SEM. Each experimental group consisted of 10 animals. (A) $* p<0.05,{ }^{* *} p<0.01, * * * p<0.001,{ }^{* * * *} p<0.0001$ vs. NaCl-treated group; ${ }^{\wedge \mu} p<0.0001$ vs. DPCPX-treated group; ${ }^{\# \#} p<0.001$ vs. istradefylline-treated group; ${ }^{++++} p<0.0001$ vs. $\mathrm{Mg}^{2+}$-treated group; \&\&\&\&\& $p<0.0001$ vs. $\mathrm{Zn}^{2+}$-treated group (two-way ANOVA followed by Bonferroni's post hoc test). (B) ${ }^{*} p<0.05,{ }^{* * * *} p<0.0001$ vs. NaCl-treated group; ${ }^{* \# \#} p<0.0001$ vs. istradefylline-treated group; \&\&\&\&\& $p<0.0001$ vs. $\mathrm{Zn}^{2+}$-treated group (two-way ANOVA followed by Bonferroni's post hoc test). (C) ${ }^{*} p<0.05$, ${ }^{* *} p<0.01$, ${ }^{* * * *} p<0.0001$ vs. NaCl-treated group; ${ }^{\wedge} p<0.001,{ }^{\wedge m} p<0.0001$ vs. DPCPX-treated group; ${ }^{\#} p<0.05$, ${ }^{\# \#} p<0.01$ vs. istradefyllinetreated group; ${ }^{++++} p<0.0001 \mathrm{vs.} \mathrm{Mg}^{2+}$-treated group; \&\&\& $p<0.001$, \&\&\&\& $p<0.0001 \mathrm{vs.} \mathrm{Zn}^{2+}$-treated group (two-way ANOVA followed by Bonferroni's post hoc test). (D) ${ }^{* * *} p<0.001{ }^{* * * *} p<0.0001 \mathrm{vs.} \mathrm{NaCl-treated} \mathrm{group;}{ }^{\wedge \wedge} p<0.0001 \mathrm{vs}$. DPCPX-treated group; ${ }^{\#} p<0.05,{ }^{\prime \prime \#} p<0.001$ vs. istradefylline-treated group; ${ }^{+} p<0.05 \mathrm{vs}$. $\mathrm{Mg}^{2+}$-treated group (two-way ANOVA followed by Bonferroni's post hoc test). (E) * $p<0.05$, ** $p<0.01$ vs. NaCl-treated group; ${ }^{*} \#$ \#\# $p<0.0001$ vs. istradefylline-treated group; ${ }^{+} p<0.05,{ }^{+++} p<0.001 \mathrm{vs}$. $\mathrm{Mg}^{2+}$-treated group; \&\& $p<0.01 \mathrm{vs.} \mathrm{Zn}^{2+}$-treated group (two-way ANOVA followed by Bonferroni's post hoc test). (F) ${ }^{* * *} p<0.001,{ }^{* * * *} p<0.0001 \mathrm{vs.} \mathrm{NaCl-treated} \mathrm{group;}{ }^{\wedge} \times p<0.0001 \mathrm{vs}$. DPCPX- treated group; ${ }^{\#} p<0.05$ vs. istradefylline-treated group; ${ }^{+++} p<0.0001 \mathrm{vs.} \mathrm{Mg}^{2+}$-treated group; \&\&\& $p<0.001$, $\& \& \& \& p<0.0001 \mathrm{vs.} \mathrm{Zn}^{2+}$-treated group (two-way ANOVA followed by Bonferroni's post hoc test).

A two-way ANOVA showed a significant interaction between DPCPX and $\mathrm{Mg}^{2+}$ $[\mathrm{F}(1,56)=36.29, p<0.0001]$ and a significant interaction between DPCPX and $\mathrm{Zn}^{2+}$ $[\mathrm{F}(1,56)=122.56, p<0.0001]$. 


\section{(2) Istradefylline and Magnesium or Zinc}

As shown in Figure 3A istradefylline injected mice alone did not cause significant changes in the expression of Adora1. The single administration of $\mathrm{Mg}^{2+}$ or $\mathrm{Zn}^{2+}$ and the co-administration of istradefylline with $\mathrm{Mg}^{2+}$ to mice resulted in a significant increase in Adora1 mRNA level as compared to the control group.

In the groups of animals that received istradefylline in a combination with $\mathrm{Zn}^{2+}$ a statistically significant increase in Adora $1 \mathrm{mRNA}$ level was observed as compared to the control group $(p<0.0001)$ and to the group received $\mathrm{Zn}^{2+}$ alone $(p<0.001)$.

A two-way ANOVA showed no interaction between istradefylline and $\mathrm{Mg}^{2+}[\mathrm{F}(1,80)=3.06$, $p=0.0839]$ and no interaction between istradefylline and $\mathrm{Zn}^{2+}[\mathrm{F}(1,80)=0.42, p=0.5202]$.

2.2.3. Effect of Co-Administration of Selective Adenosine Receptor Antagonists and Magnesium or Zinc on Slc6a15 Expression

(1) DPCPX and Magnesium or Zinc

As shown in Figure $3 \mathrm{~B} \mathrm{Mg}^{2+}$ and $\mathrm{Zn}^{2+}$ injected alone caused a significant decrease the mRNA level of Slc6a15 in comparison to the control group $(p<0.05$ and $p<0.0001$, respectively), while DPCPX did not cause statistically significant changes in Slc6a15 gene expression $(p>0.05)$. Additionally, DPCPX co-administered with $\mathrm{Mg}^{2+}$ did not cause significant changes in the expression of this gene. However, the co-administration of DPCPX with $\mathrm{Zn}^{2+}$ resulted in a significant increase in Slc6a15 mRNA levels as compared to the group receiving only $\mathrm{Zn}^{2+}(p<0.0001)$.

A two-way ANOVA showed no interaction between DPCPX and $\mathrm{Mg}^{2+}[\mathrm{F}(1,56)=0.56$, $p=0.4584]$ and a significant interaction between DPCPX and $\mathrm{Zn}^{2+}[\mathrm{F}(1,56)=17.77, p<0.0001]$.

(2) Istradefylline and Magnesium or Zinc

As shown in Figure 3B both istradefylline and $\mathrm{Mg}^{2+}$ as well as $\mathrm{Zn}^{2+}$ injected alone caused a significant decrease in the mRNA level of Slc6a15 in comparison to the control group ( $p<0.0001, p<0.05$ and $p<0.0001$, respectively). Istradefylline and $\mathrm{Mg}^{2+}$ administered simultaneously caused a significant decrease in the Slc6a15 expression in comparison to the control group $(p<0.0001)$ and a significant increase in comparison to the istradefylline-treated group $(p<0.0001)$. However, istradefylline co-administered with $\mathrm{Zn}^{2+}$ resulted in a significant increase in Slc6a15 mRNA levels as compared to the istradefylline-treated group $(p<0.0001)$ as well as $\mathrm{Zn}^{2+}$-treated group $(p<0.0001)$.

A two-way ANOVA showed a significant interaction between istradefylline and $\mathrm{Mg}^{2+}$ $[\mathrm{F}(1,80)=24.26, p<0.0001]$ and a significant interaction between istradefylline and $\mathrm{Zn}^{2+}$ $[\mathrm{F}(1,80)=81.06, p<0.0001]$.

2.2.4. Effect of Co-Administration of Selective Adenosine Receptor Antagonists and Magnesium or Zinc on Comt Expression

(1) DPCPX and Magnesium or Zinc

As shown in Figure $3 \mathrm{C}$ both DPCPX and $\mathrm{Mg}^{2+}$ as well as $\mathrm{Zn}^{2+}$ administered alone caused a significant increase in the mRNA level of Comt in comparison to the control group $(p<0.05, p<0.01$ and $p<0.0001$, respectively). However, DPCPX co-administered with $\mathrm{Mg}^{2+}$ caused a significant decrease in the Comt expression in comparison to the control group $(p<0.01)$, to the to the DPCPX-treated group $(p<0.0001)$ and also to the $\mathrm{Mg}^{2+}$ treated group $(p<0.0001)$. Similarly, the simultaneously administration to mice the DPCPX with $\mathrm{Zn}^{2+}$ resulted in a significant reduction in Comt mRNA levels both compared to the DPCPX-treated group $(p<0.001)$ and to the group receiving only $\mathrm{Zn}^{2+}(p<0.0001)$.

A two-way ANOVA showed a significant interaction between DPCPX and $\mathrm{Mg}^{2+}$ $[\mathrm{F}(1,56)=35.53, p<0.0001]$ and a significant interaction between DPCPX and $\mathrm{Zn}^{2+}$ $[\mathrm{F}(1,56)=53.64, p<0.0001]$.

(2) Istradefylline and Magnesium or Zinc 
As shown in Figure $3 \mathrm{C}$ both istradefylline and $\mathrm{Mg}^{2+}$ as well as $\mathrm{Zn}^{2+}$ injected alone caused a significant increase in the mRNA level of Comt in comparison to the control group $\left(p<0.01, p<0.01\right.$ and $p<0.0001$, respectively). Istradefylline and $\mathrm{Mg}^{2+}$ administered simultaneously caused a significant decrease in the Comt expression in comparison to the groups received alone istradefylline or $\mathrm{Mg}^{2+}(p<0.01$ and $p<0.0001$, respectively). In turn, the co-administration of istradefylline with $\mathrm{Zn}^{2+}$ to mice resulted in a significant increase in Comt mRNA levels as compared to the control group $(p<0.01)$ and a significant decrease as compared to the group received only istradefylline or $\mathrm{Zn}^{2+}(p<0.05$ and $p<0.001$, respectively).

A two-way ANOVA showed a significant interaction between istradefylline and $\mathrm{Mg}^{2+}$ $[\mathrm{F}(1,80)=27.27, p<0.0001]$ and a significant interaction between istradefylline and $\mathrm{Zn}^{2+}$ $[\mathrm{F}(1,80)=23.71, p<0.0001]$.

2.2.5. Effect of Co-Administration of Selective Adenosine Receptor Antagonists and Magnesium or Zinc on Ogg1 Expression

(1) DPCPX and Magnesium or Zinc

As shown in Figure 3D neither DPCPX nor $\mathrm{Mg}^{2+}$ nor $\mathrm{Zn}^{2+}$ caused statistically significant changes in $O g g 1$ gene expression $(p>0.05)$ as compared to the control group. Additionally, DPCPX co-administered with $\mathrm{Mg}^{2+}$ did not cause significant changes in the expression of this gene. However, the co-administration of DPCPX with $\mathrm{Zn}^{2+}$ resulted in a significant reduction in $O g g 1$ mRNA levels both compared to the control group $(p<0.0001)$ and to the group receiving only DPCPX $(p<0.0001)$.

A two-way ANOVA showed no interaction between DPCPX and $\mathrm{Mg}^{2+}[\mathrm{F}(1,56)=0.96$, $p=0.3323]$ and a significant interaction between DPCPX and $\mathrm{Zn}^{2+}[\mathrm{F}(1,56)=8.49, p=0.0051]$.

(2) Istradefylline and Magnesium or Zinc

As shown in Figure 3D neither $\mathrm{Mg}^{2+}$ nor $\mathrm{Zn}^{2+}$ caused statistically significant changes in $O g g 1$ gene expression $(p>0.05)$ but istradefylline injected alone caused a significant decrease in the mRNA level of $O g g 1$ in comparison to the control group $(p<0.001)$. Istradefylline and $\mathrm{Mg}^{2+}$ administered simultaneously caused a significant increase in the Ogg1 expression in comparison to istradefylline-treated group $(p<0.05)$ and significant decrease in comparison to $\mathrm{Mg}^{2+}$-treated group $(p<0.05)$. Istradefylline and $\mathrm{Zn}^{2+}$ injected simultaneously caused significant increases the $O g g 1$ mRNA level in comparison to istradefylline-treated group $(p<0.001)$.

A two-way ANOVA showed no interaction between istradefylline and $\mathrm{Mg}^{2+}[\mathrm{F}(1,80)=0.45$, $p=0.5050]$ and a significant interaction between istradefylline and $\mathrm{Zn}^{2+}[\mathrm{F}(1,80)=8.51, p=0.0046]$.

2.2.6. Effect of Co-Administration of Selective Adenosine Receptor Antagonists and Magnesium or Zinc on Msra Expression

(1) DPCPX and Magnesium or Zinc

As shown in Figure 3E neither DPCPX nor $\mathrm{Mg}^{2+}$ nor $\mathrm{Zn}^{2+}$ caused statistically significant changes in MsrA gene expression $(p>0.05)$ as compared to the control group. DPCPX co-administered with $\mathrm{Zn}^{2+}$ did not cause significant changes in the mRNA level of this gene while the co-administration of DPCPX with $\mathrm{Mg}^{2+}$ resulted in a significant increase in MsrA mRNA levels both comparison to the control group $(p<0.05)$ and to the group receiving only $\mathrm{Mg}^{2+}(p<0.001)$.

A two-way ANOVA showed no interaction between DPCPX and $\mathrm{Mg}^{2+}[\mathrm{F}(1,56)=3.87$, $p=0.0542]$ and no interaction between DPCPX and $\mathrm{Zn}^{2+}[\mathrm{F}(1,56)=0.07, p=0.7929]$.

\section{(2) Istradefylline and Magnesium or Zinc}

As shown in Figure 3E, istradefylline injected alone significantly decreased the mRNA level of MsrA in comparison to the control group $(p<0.05)$ while neither $\mathrm{Mg}^{2+}$ nor $\mathrm{Zn}^{2+}$ caused statistically significant changes in MsrA gene expression $(p>0.05)$. In the groups of animals that received istradefylline in combination with $\mathrm{Mg}^{2+}$ a statistically significant 
decrease in MsrA mRNA level was observed as compared to the control group $(p<0.001)$ and to the group receiving $\mathrm{Mg}^{2+}$ alone $(p<0.05)$. In the cerebral cortex of mice receiving istradefylline simultaneously with $\mathrm{Zn}^{2+}$ the statistically significant increase in the expression of the $M s r A$ gene was observed as compared to the group receiving only istradefylline $(p<0.0001)$ or $\mathrm{Zn}^{2+}(p<0.001)$.

A two-way ANOVA showed no interaction between istradefylline and $\mathrm{Mg}^{2+}[\mathrm{F}(1,80)=0.18$, $p=0.6711]$ and a significant interaction between istradefylline and $\mathrm{Zn}^{2+}[\mathrm{F}(1,80)=14.96$, $p=0.0002]$.

2.2.7. Effect of Co-Administration of Selective Adenosine Receptor Antagonists and Magnesium or Zinc on Nrf2 Expression

(1) DPCPX and Magnesium or Zinc

As shown in Figure 3F $\mathrm{Zn}^{2+}$ injected alone significantly decreased the mRNA level of Nrf2 as compared to the control group $(p<0.0001)$. $\mathrm{Mg}^{2+}$ administered to mice did not cause significant changes in Nrf2 gene expression while DPCPX significantly increased the expression of this gene $(p<0.0001)$. On the contrary, DPCPX administered simultaneously with $\mathrm{Mg}^{2+}$ or $\mathrm{Zn}^{2+}$ significantly decreased the Nrf2 mRNA level as compared to the group of mice receiving DPCPX alone $(p<0.0001)$.

A two-way ANOVA showed a significant interaction between DPCPX and $\mathrm{Mg}^{2+}$ $[\mathrm{F}(1,56)=40.43, p<0.0001]$ and a significant interaction between DPCPX and $\mathrm{Zn}^{2+}$ $[\mathrm{F}(1,56)=118.80, p<0.0001]$.

(2) Istradefylline and Magnesium or Zinc

As shown in Figure $3 \mathrm{~F}$ in the cerebral cortex of mice receiving istradefylline or $\mathrm{Zn}^{2+}$ alone the significant decrease in expression of $N r f 2$ as compared to the control group was observed $(p<0.0001)$ while in the brain of mice receiving $\mathrm{Mg}^{2+}$ no statistically significant changes were noted. However, istradefylline and $\mathrm{Mg}^{2+}$ administered simultaneously caused a significant decrease in the Nrf2 expression in comparison to the control and to the $\mathrm{Mg}^{2+}$-treated group $(p<0.0001)$ and a significant decrease in comparison to the $\mathrm{Mg}^{2+}$-treated group $(p<0.05)$. In turn, the co-administration of istradefylline and $\mathrm{Zn}^{2+}$ resulted in a significant increase in Nrf 2 mRNA levels as compared to the group receiving only $\mathrm{Zn}^{2+}(p<0.001)$.

A two-way ANOVA showed no interaction between istradefylline and $\mathrm{Mg}^{2+}[\mathrm{F}(1,80)=3.08$, $p=0.0832]$ and a significant interaction between istradefylline and $\mathrm{Zn}^{2+}[\mathrm{F}(1,80)=50.70$, $p<0.0001]$.

\section{Discussion}

\subsection{Behavioural Studies}

In the present studies, firstly we have evaluated the synergistic antidepressant-like activity of DPCPX — selective antagonist of adenosine A1 receptor and istradefyllineselective antagonist of adenosine $\mathrm{A} 2 \mathrm{~A}$ receptor, with the magnesium and zinc ions in two commonly used despair behavioural tests (FST and TST). The FST and TST are well-characterized rodent's tests carried out to predict the antidepressant-like efficacy of agents or agent-agent combinations $[34,35]$. In our research only male mice were used, in accordance with the common practice in preclinical experiments assessing the antidepressant-like effects of the active substances. The exclusion of female mice from these tests is primarily due to the presence of the oestrous cycle, thought to interfere with experimental manipulations by introducing variability, which is a less critical issue in male animals. Moreover, in order to rule out that the changes in the overall mobility of mice are not disruptive factors in these tests, a spontaneous locomotor activity test was conducted. Since no augmentation in the mice locomotor activity was observed (in the case of using $\mathrm{Zn}$ alone and $\mathrm{Zn}$ in combined with DPCPX decrease in animals' activity was noted), the received outcomes indicate synergistic interaction between $\mathrm{Mg}^{2+} / \mathrm{Zn}^{2+}$ and DPCPX/istradefylline (all in ineffective doses: $10 / 2.5 \mathrm{mg} / \mathrm{kg}$ and $1 / 0.5 \mathrm{mg} / \mathrm{kg}$, re- 
spectively) manifested in a meaningful enhancement of mice mobility in the FST and TST, which indicates antidepressant-like properties of such treatment schedule.

The same trend obtained in both conducted behavioural tests exclude the possibility of impact of various environmental factors on the presented results. In the case of the tested combination of DPCPX with $\mathrm{Mg}^{2+}$ or $\mathrm{Zn}^{2+}$, a small but statistically significant decrease in mice immobility in the FST was noted, whereas in the TST the observed difference was significantly higher. In turn, when studying the combination of istradefylline and $\mathrm{Mg}^{2+}$ or $\mathrm{Zn}^{2+}$, in both tests statistically meaningful changes were recorded at the same level. The decrease in mice immobility in the FST compared to that found in the TST is usually not identical, because these procedures are differently sensitive to various drugs. For drugs, that exhibit in the TST, while not consistently reducing immobility in the FST, include the selective serotonin reuptake inhibitors (SSRIs) [34,36]. In turn, some non-typical drugs (i.e., rolipram and levoprotillin) show antidepressant-like activity in the FST, but not in the TST [36,37], whereas shortening the immobility time in both the FST and TST is observed when using drugs, such as tricyclic antidepressants (TCAs), monoamine oxidase inhibitors (MAOIs), atypical antidepressant (i.e., mianserin) [36,38,39], and also antagonists of the NMDA $[36,40,41]$ and agonists of the AMPA receptor [42]. As demonstrated in our previous research, A1 and A2A receptor antagonists also have antidepressant-like activity in both of these behavioural tests [31,32]. Though both these despair behavioural tests are generally based on the same principle, the neurological mechanisms underlying the observed antidepressant effect are different, which may be the reason for the observed disagreement between the antidepressant-like activity of various compounds in the FST and TST [36]. The dissimilarities in the neurotransmitter mechanisms may also be the basis of the disparities noted in our research. The adenosine A1 receptors are highly localized in the CNS, and their inhibition by DPCPX causes stimulation of voltage dependent $\mathrm{Ca}^{2+}$ channels, lock of $\mathrm{K}^{+}$ channels resulting in extenuation of hyperpolarisation and activation of adenylyl cyclase. All of them lead to an enhancement in the release of mainly monoaminergic transmitters (i.e., serotonin, noradrenalin, dopamine) [43-45]. Conversely, A2A receptors inhibition has no impact or decreases the release of these neurotransmitters [45]. Regarding glutamatergic transmission, the effect of $\mathrm{A} 1$ and $\mathrm{A} 2 \mathrm{~A}$ receptor antagonists is reversed, i.e., blockage of A1 receptors causes stimulation, and A2A receptors blockage of release of glutamate [46-51]. Additionally, the different effects of DPCPX and istradefylline on the antidepressant activity of NMDA receptor ion ligands observed in our studies may result from receptor-receptor interaction in the $\mathrm{A} 1-\mathrm{A} 2 \mathrm{~A}$ receptor complex on the striatal glutamatergic nerve terminals. Ciruela et al. [22] demonstrated that the preferential A1 receptor activation in the A1-A2A receptor complex inhibits glutamatergic neurotransmission. In turn, under conditions of high adenosine release, $\mathrm{A} 2 \mathrm{~A}$ receptor activation in the $\mathrm{A} 1-\mathrm{A} 2 \mathrm{~A}$ heteromer complex blocks mediated via A1 receptors function, and enhances release of glutamate [20,22]. Thus, the selective inhibition of $\mathrm{A} 1$ and $\mathrm{A} 2 \mathrm{~A}$ receptors in this complex might facilitate or inhibit glutamatergic transmission, respectively. Furthermore, Borroto-Escuela et al. [52], based on previous studies, suggest occurrence A2A-D2-NMDA heteroreceptors complexes in the striato-pallidal GABA neurons in a synaptic and/or extrasynaptic position, as well as in lower densities in cortical regions. It may, therefore, be considered that istradefylline, by inhibiting the activity of the A2A receptor, could stimulate the D2 receptor function, which inhibits NMDA receptor signalling in this heteroreceptor complex.

Several recent studies have demonstrated the synergistic interaction between adenosinergic and glutamatergic systems $[30,53,54]$, but none of them investigated the interaction between the selective adenosine $\mathrm{A} 1$ and $\mathrm{A} 2 \mathrm{~A}$ receptor antagonists and magnesium ions in despair tests in mice. Likewise, in the case of the combinations of the selective A1 and $\mathrm{A} 2 \mathrm{~A}$ receptor antagonists with $\mathrm{Zn}^{2+}$ ions tested in presented studies, we obtained results that were in contradiction with those obtained by Lobato et al. [55]. The differences between the outcomes of behavioural tests carried out by our team and those conducted by Lobato et al. [55] may result from the use of other zinc salts and doses (zinc hydroaspartate $2.5 \mathrm{mg} / \mathrm{kg}$ and zinc chloride $30 \mathrm{mg} / \mathrm{kg}$, respectively), other doses of DPCPX $(1 \mathrm{mg} / \mathrm{kg}$ and 
$2 \mathrm{mg} / \mathrm{kg}$, respectively), and alternative selective antagonist of A2A adenosine receptors at various doses (KW-6002 $0.5 \mathrm{mg} / \mathrm{kg}$ and ZM241385 $1 \mathrm{mg} / \mathrm{kg}$, respectively). Additionally, the research presented in this manuscript was executed on male Albino Swiss mice, while the Lobato team performed despair test using mice of either sex. As is well-known and well-documented, gender differences can have a significant impact on depressive behaviour in rodents [55-58]. One more difference is the FST methodology, specifically the time at which the immobility of animals was evaluated. Lobato et al. [55] recorded the total duration of immobility during the whole $6 \mathrm{~min}$ period of behavioural testing (methodology described by Kaster et al. [59]), while in our studies the total duration of mice immobility was measured between 2 and 6 min of the experiment (methodology described by Porsolt et al. [60]).

Already in 1982 it was noted that, in the animal models, adenosine receptor agonists counteracted behavioural changes induced by of NMDA receptor antagonists [61]. Additionally, Popoli et al. [62] demonstrated that, in rats, adenosine A1 and A2A receptor agonists also prevent neurophysiological changes (i.e., the electroencephalographic effects) caused by the NMDA receptor antagonist (MK-801). In turn, Serefko et al. [30] and Bespalov et al. [53] demonstrated a synergistic interaction between a non-selective adenosine receptor antagonist, caffeine, and NMDA receptor antagonists. Obtained results indicated that, caffeine, only in the low dose ranges, given jointly with the NMDA receptor channel blocker (MK-801, 0.01-0.3 mg/ kg), or a competitive antagonist (D-CPPene, $0.3-5.6 \mathrm{mg} / \mathrm{kg}$ ) to rats significantly lowered brain stimulation reward thresholds [53]. Serefko and co-workers [30] demonstrated that caffeine injected concurrently at inactive dose $(5 \mathrm{mg} / \mathrm{kg}$ ) with the NMDA receptor antagonists, MK-801, L-701,324 or CGP 37849, also at non-effective doses $(0.05,1,0.3 \mathrm{mg} / \mathrm{kg}$, respectively) significantly decreased the immobility time of mice in the FST. The same antidepressant-like activity was observed in mice receiving caffeine in combination with a partial agonist of a glycine recognition site (D-cycloserine, $2.5 \mathrm{mg} / \mathrm{kg}$ ) [30]. This scientific team examined also the effect of caffeine, on the antidepressant-like activity of magnesium ions in the FST in mice [30]. Unlike in the case of this study, they observed lack of a synergistic interaction between magnesium or zinc hydroaspartate and caffeine.

The explanation for interactions between adenosine and glutamatergic system indicated in our, and the other mentioned studies may be the mechanism described by Craig and White [63] and confirmed by Manzoni et al. [64] and Melani et al. [65]. Those reports showed that adenosine release in rat brain structures (i.e., cortex and striatum) is enhanced by stimulation of the NMDA receptor [63-65]. Contrariwise, the effects mediated via these receptors are mitigated by adenosine receptor activation [66].

\subsection{BDNF Level Analysis}

Clinical and animal studies confirm that depression is associated with neuronal atrophy and neuronal cell loss, especially in the cerebral cortex and hippocampus $[67,68]$. Therefore, for a better understanding of the pathogenesis of depression and the mechanisms of action of antidepressants, neurotrophic factors are considered [69]. The neurotrophic hypothesis of depression suggests that the deficiency of neurotrophic factors contributes to the pathology of the brain structures during the development of the disease, and that antidepressants may reverse this deficiency and, thus, contribute to the alleviation of symptoms of depression [70,71]. Of the many neurotrophins, most research focuses on BDNF, one of the most common neurotrophic factors in adult human and animal brains. BDNF is a protein that, in humans, is encoded by the BDNF gene; it is a member of the neurotrophin family of growth factors, which are related to the canonical nerve growth factor. BDNF is believed to play an important role in memory formation and learning [72]. Studies have shown that drugs can act as an antidepressant through BDNF-dependent neurotrophic/neuroplastic mechanisms [73].

The neurotrophic hypothesis of depression indicates that alterations in BDNF levels occur in key limbic structures to contribute to the pathogenic processes [74,75]. Up-regulation of this factor occurs in the amygdala and nucleus accumbens of persons with depression 
whereas down-regulation of BDNF occurs in the prefrontal cortex and hippocampus [76]. Animal studies have shown that BDNF is able to cross the blood-brain barrier in both directions and that central and peripheral BDNF levels are related [77,78]. Changes in levels of BDNF in the serum of patients with depressive disorders emphasize the potential of BDNF as a biomarker [77]. Since the levels of BDNF in the brain in patients suffering from depression are impossible to measure, the determination of the level of BDNF in the blood is possible [79]. Studies in rodents have shown that blood BDNF concentrations correlate positively with BDNF levels in the frontal cortex and hippocampus and support the notion that blood BDNF levels measurements reflect BDNF levels in brain tissue $[77,80]$. In our study, we did not observe statistically significant changes in BDNF levels in the serum of mice receiving magnesium or zinc hydroaspartate alone or the selective $\mathrm{A} 1$ or $\mathrm{A} 2 \mathrm{~A}$ receptor antagonists. However, in the groups of mice receiving DPCPX with $\mathrm{Mg}^{2+}$ and istradefylline with $\mathrm{Mg}^{2+}$ or $\mathrm{Zn}^{2+}$ a significant reduction in BDNF concentration was noted, both compared to the control group and to the groups with a single administration of the substances. The obtained data, especially in relation to the results of behavioural tests, may seem surprising, because, as mentioned above, one of the mechanisms of antidepressant activity includes increasing the concentration of BDNF in the brain. Perhaps the explanation for the lack of changes in the expression of this neurotrophic factor is the duration of the experiment. This prediction may be confirmed by research which has shown that up-regulation of BDNF occurs following chronic administration of antidepressants consistent with the time course for the therapeutic action of antidepressants [71,81]. Nibuya et al. [82] confirmed that chronic (21 days), but not acute (1 day), administration of several antidepressants significantly increased BDNF mRNA in the brain [82]. However, it should be emphasized that in groups of animals receiving DPCPX with $\mathrm{Mg}^{2+}$ and istradefylline with $\mathrm{Mg}^{2+}$ or $\mathrm{Zn}^{2+}$ a significant decrease in BDNF concentration was observed. Studies have shown that a lower BDNF level in prefrontal cortex function might modulate the synergistic effects of serotonergic and autonomic nervous system in order to maintain brain physiological and psychological homeostasis [83]. Perhaps the changes observed in our study may also be related to the above hypothesis, i.e., the desire to maintain homeostasis in the CNS during acute stress. In order to clarify this issue, further studies on the effect of the investigational drugs on the level of BDNF also after long-term administration are necessary.

\subsection{Gene Expression Analysis}

Finally, in the prefrontal cortex of mice the mRNA levels of the following genes: Adora1 (adenosine A1 receptor), encoding A1 receptor [84], Slc6a15 (solute carrier family 6 member 15), encoding a transporter with the neutral amino acid transporters subfamily of the Slc6 family [85], and Comt (catechol-O-methyltransferase), an encoding enzyme responsible for the degradation of catecholamine neurotransmitters [86] have been measured. Moreover, the mRNA expression of DNA-repairing genes (the 8-oxoguanine glycosylase-1, $O g g 1$, and methionine sulfoxide reductase $M s r A$ ) and gene-encoding antioxidative transcriptional factor (nuclear factor 2-related factor 2, Nrf2) were determined.

In our study we have evaluated the expression of the selected genes, which may play a role in the pathophysiology and treatment of depression or the mechanism of DPCPX and istradefylline action (i.e., Adora1, Slc6a15, Comt). Some research shows the potential link between the improvement of the A1 receptor signalling and the antidepressant effect on people suffering from depressive disorders. Adora1 is a gene encoding the A1 receptor. Substances that have selective impact on them may have neuroprotective function [87]. Adenosine, as an endogenous agonist of these receptors, provokes inhibition of secretion neurotransmitters from the cells, which may cause reduction of nerve cells and neuronal transmission excitability [88]. Substances that inhibit the action of adenosine contribute to an increase in the concentration of neurotransmitters and intensity of neurotransmission [89]. In our study, we did not observe significant changes in the Adora1 gene expression in the cerebral cortex of mice receiving DPCPX or istradefylline alone. In turn, mice pretreated with $\mathrm{Mg}^{2+}, \mathrm{Zn}^{2+}, \mathrm{DPCPX}$ with $\mathrm{Zn}^{2+}$ and istradefylline with $\mathrm{Mg}^{2+}$ or $\mathrm{Zn}^{2+}$ 
showed an increased expression of this gene, relative to control. The observed increase in expression of this gene may be due to an increase in the concentration of neurotransmitters, since increased neurotransmission may lead to stimulation of the A1 receptor. Studies have shown that the increase of A1 expression evokes resilience against depressive-like behaviour in the behavioural tests and the antidepressant effects in animal chronic stress model [84]. Interestingly, DPCPX administered to mice in combination with $\mathrm{Mg}^{2+}$ causes a reduction in expression of this gene, however, when administered to mice in combination with $\mathrm{Zn}^{2+}$ it significantly increases its expression. Perhaps the reason for these differences are the complex mechanisms of interaction between the adenosine and glutamatergic systems associated with different types of receptors.

It is possible that the Slc6a15 gene is associated with the major depressive disorder. The research proves the relation between chronic stress in mice and down-regulation of the Slc6a15 in the hippocampus. Potentially, these changes lead directly to alterations in the hippocampal volume and the integrity of neurons [90]. It has been showed, that the decreased Slc6a15 expression, due to genetic or environmental factors, might alter neuronal circuits related to the susceptibility for major depression [90]. The lower Slc6a15 expression, especially in the hippocampus, could increase stress susceptibility, also by altering excitatory neurotransmission in the brain. The studies show that the Slc6a15 plays a role in modulating emotional behaviour, possibly mediated by its impact on glutamatergic neurotransmission [91]. A decreased expression of this gene may lead to disturbances around the neuronal conduction, thus, the Slc6a15 protein may be the grip point for drugs which affect its function [90]. A decreased expression of Slc6a15 was noted in the cerebral cortex of mice receiving only istradefylline, $\mathrm{Mg}^{2+}, \mathrm{Zn}^{2+}$ and simultaneously istradefylline with $\mathrm{Mg}^{2+}$. Therefore, the reduction in the mRNA level of Slc6a15 seems to be related to the inhibitory effect on glutamatergic transmission through antagonism of NMDA receptor complex. However, co-administration of DPCPX with $\mathrm{Zn}^{2+}$ and istradefylline with $\mathrm{Zn}^{2+}$ resulted in an increase of the mRNA level of Slc6a15 as compared to the single drug administration, which may indicate beneficial effects. Perhaps these results may be explained by modulation of the activity of another ionotropic and metabotropic glutamate receptors by $\mathrm{Zn}^{2+}$.

Comt is one of the most important enzymes connected with the disintegration of catecholamines [92]. The enzyme accelerates the process of transferring methyl groups from S-adenosylmethionine to catecholamines. There are studies, which proved an interaction between the Comt gene expression and depressive disorders, whose development may be caused by some alterations of the Comt in the prefrontal cortex [93]. Antidepressants, by enhancing catecholamine transmission, may affect the activity of enzymes involved in their metabolism [92]. In our work, we observed an increase in Comt expression, as compared to controls, in groups of mice receiving only DPCPX, istradefylline, $\mathrm{Mg}^{2+}$ or $\mathrm{Zn}^{2+}$. The explanation for these changes may be a theory which assumes that these drugs cause an increase in the level of catecholamine in the brain, hence the activity of Comt as the enzyme responsible for the breakdown of catecholamines is higher. This could probably be a compensatory mechanism in response to higher catecholamine production. However, it should be noted that a decrease in the Comt gene expression was observed in the group of mice receiving DPCPX with $\mathrm{Mg}^{2+}$ (similar to Adora1 expression). In order to understand this effect further research is required. In the remaining groups, no statistically significant changes in the expression of the determined gene were noted while compared to the control, however, the obtained results do not indicate a more favourable effect of combined drug administration in this respect.

In the last stage of our research the expression of selected antioxidant defence genes (i.e., $O g g 1$, MsrA and Nrf2) were determined. $O g g 1$ gene is a key component of the base excision repair pathway; $O g g 1$ encodes the enzyme responsible for excision of a mutagenic base by-product (8-oxoguanine) that occurs as a result of exposure to reactive oxygen species (ROS) [94]. In patients with depression, increased concentrations of oxidative damage markers were detected, including 8-oxoguanine, a product of guanine oxidation, 
as well as malondialdehyde, a compound formed in the process of lipid peroxidation [95]. Induced by oxidative stress, the $O g g 1$ gene is expressed in the brain and can be a cellular marker for oxidative DNA damage $[96,97]$. The current study revealed a significant decrease in the mRNA level of $O g g 1$ in the prefrontal cortex of mice receiving istradefylline or DPCPX with $\mathrm{Zn}^{2+}$ in comparison to the control group, which may indicate potential benefits in terms of antioxidant capacity. Similarly, a lower mRNA level of MsrA was observed in the brain of mice receiving istradefylline or istradefylline and $\mathrm{Mg}^{2+}$ compared to the control group. MsrA plays an important role in providing cells with defence against oxidative stress. It is an enzyme that catalyses the thioredoxin-dependent reduction of free and protein-bound methionine sulfoxide (MetO) to methionine. The methionine residues bound to the protein are particularly susceptible to oxidation by ROS [98]. In addition, $M s r A$ can be used to repair oxidatively damaged proteins [99]. Yeast cells and bacteria, deficient in the MsrA gene, are more sensitive to oxidative stress, while over-expression of MsrA in human T lymphocytes results in an increase in life expectancy under oxidative stress conditions. The MsrA protein has the highest expression in cells sensitive to oxidative damage, among others in the cerebellum and brain neurons [98]. The reported reduction in expression of DNA repair enzymes may indicate a reduction of oxidative damage and, thus, may suggest protection against oxidative stress.

A statistically significant increase in Nrf2 gene expression was observed in the cerebral cortex of mice receiving DPCPX alone, as well as DPCPX with $\mathrm{Mg}^{2+}$ as compared to the control group. An increase in expression of this gene was also noted in the groups of mice treated with DPCPX with $\mathrm{Zn}^{2+}$ and istradefylline with $\mathrm{Zn}^{2+}$ as compared to $\mathrm{Zn}^{2+}$ alone. In turn, a reduction in Nrf2 expression as compared to the controls was observed in the brain of mice receiving istradefylline, istradefylline with $\mathrm{Mg}^{2+}$ as well as $\mathrm{Zn}^{2+}$ alone. A reduction in the mRNA level of Nrf2 was also observed in the group of mice receiving DPCPX in combination with $\mathrm{Zn}^{2+}$ as compared to DPCPX alone. The role of Nrf2 in the mechanisms involved in neuroprotection is crucial for determining new strategies of treatment of neurodegenerative diseases. Nrf2 is mainly activated by ROS [100]. Recent reports indicate the protective function of $N r f 2$ in various pathological states, including ischemia and neurodegenerative diseases [101]. It has been proved that the nerve cells treated with chemical activators of the Nrf2-ARE pathway (tBHQ, sulforaphane) are more resistant to oxidative stress-induced neurotoxicity [102]. In vitro studies have also shown that astrocytes with increased expression of the Nrf2 coding gene, resulting from adenoviral vectors, may protect the nerve cells from the effects of oxidative stress caused by hydrogen peroxide [103]. On the other hand, the lowering $N r f 2$ expression results in an increased sensitivity of neurons and astrocytes to oxidative stress. This is due to the reduction of both constitutive and inducible expression of cytoprotective genes [104]. Nrf2 is also a transcription factor that controls the expression of detoxification and antioxidant enzymes, therefore, while interpreting the above results changes in the oxidative stress response genes should be taken into account. DPCPX administered to mice does not cause any changes in the expression of $O g g 1$ and MsrA but significantly increases the expression of Nrf2, what may indicate its beneficial effect. However, the observed change may also suggest an excessive increase in ROS generation, because Nrf2 is activated by oxidative stress. $\mathrm{Mg}^{2+}$ administered to mice did not affect the changes of antioxidant defence gene expression. However, $\mathrm{Zn}^{2+}$ significantly decreased the expression of $\mathrm{Nrf2}$, proving a potentially disadvantageous effect in this regard. The increased expression of Nrf2 and MsrA resulting from administration of DPCPX together with $\mathrm{Mg}^{2+}$ may support the hypothesis of excess ROS and activation of the Nrf2 pathway. In contrast, DPCPX in combination with $\mathrm{Zn}^{2+}$ causes a reduction in $O g g 1$ expression and does not significantly affect the change of the transcription factor expression relative to control, which may indicate a beneficial influence on defence against excess ROS formation. Istradefylline administered alone decreases the expression of repair genes, suggesting a lack of oxidative DNA damage. However, given the significant reduction in the mRNA level of Nrf2, it can be assumed that these changes are dependent on the level of transcription factor, 
which induces reduced protection against oxidative stress. Similar changes were noted in the group of mice receiving istradefylline with $\mathrm{Mg}^{2+}$. In turn, the co-administration of istradefylline with $\mathrm{Zn}^{2+}$ does neither decrease the $\mathrm{Nrf2}$ expression nor change the expression of oxidative stress response genes in regard to the control, which may suggest a more favourable effect than administration of istradefylline alone.

\section{Materials and Methods}

\subsection{Animals}

Naïve 10-week-old male Albino Swiss mice $(n=180)$ weighing $25-30$ g purchased from the licensed breeder (Experimental Medicine Centre, Lublin, Poland) were used for all experiments. The animals were kept in standard cages (10 mice each) in the laboratory rooms with strictly controlled housing conditions-12 h light/dark cycle (light on at 6:00 a.m. light of at 6:00 p.m.), temperature $21-23{ }^{\circ} \mathrm{C}$, relative humidity $45-55 \%$. Throughout the study, the animals had unrestricted access to chow pellets and tap water. To minimize circadian influences all procedures were conducted between 8 a.m. and 3 p.m. The experimental groups consisted of 8-10 mice, randomly assigned prior the drug administration. Behavioural tests were analysed by two blind observers.

\subsection{Drugs}

The following substances were used: DPCPX (8-cyclopentyl-1,3-dipropylxanthine, Sigma-Aldrich, Poznań, Poland), istradefylline (KW-6002, (E)-8-(3,4-dimethoxystyryl)1,3-diethyl-7-methylxanthine, Sigma-Aldrich, Poznań, Poland), magnesium hydroaspartate (Farmapol, Poznań, Poland), and zinc hydroaspartate (Farmapol, Poznań, Poland). DPCPX $(1 \mathrm{mg} / \mathrm{kg})$ and istradefylline $(0.5 \mathrm{mg} / \mathrm{kg})$ were suspended in a $0.9 \%$ saline with Tween 80 (1\%) (POCH, Gliwice, Poland), whereas magnesium and zinc hydroaspartate (10 mg/ $\mathrm{kg}$ and $2.5 \mathrm{mg} / \mathrm{kg}$, calculated as pure magnesium or zinc ions, respectively) were dissolved in $0.9 \%$ saline. DPCPX and magnesium hydroaspartate were injected intraperitoneally (i.p.) $30 \mathrm{~min}$, while istradefylline was administered orally (p.o.) and zinc hydroaspartate i.p. $60 \mathrm{~min}$ before behavioural testing. Animals from control group were given $0.9 \%$ saline. All liquid dosage forms were prepared immediately prior to the experiments and they were administered in a volume of $0.01 \mathrm{~mL} / \mathrm{g}$.

The treatment schedules and subtherapeutic doses of DPCPX, $\mathrm{Mg}^{2+}$ and $\mathrm{Zn}^{2+}$ were chosen on the basis of our previous projects [30,31], whereas of istradefylline were selected on the basis of literature data [105] and then confirmed in preliminary studies carried out in our laboratory.

\subsection{Treatment Schedule}

1st group: saline + saline; 2nd group: DPCPX $1 \mathrm{mg} / \mathrm{kg}+$ saline; 3rd group: istradefylline $0.5 \mathrm{mg} / \mathrm{kg}$ + saline; 4th group: $\mathrm{Mg}^{2+} 10 \mathrm{mg} / \mathrm{kg}$ + saline; 5 th group: DPCPX $1 \mathrm{mg} / \mathrm{kg}$ $+\mathrm{Mg}^{2+} 10 \mathrm{mg} / \mathrm{kg}$; 6th group: istradefylline $0.5 \mathrm{mg} / \mathrm{kg}+\mathrm{Mg}^{2+} 10 \mathrm{mg} / \mathrm{kg}$; 7 th group: $\mathrm{Zn}^{2+}$ $2.5 \mathrm{mg} / \mathrm{kg}+$ saline; 8th group: DPCPX $1 \mathrm{mg} / \mathrm{kg}+\mathrm{Zn}^{2+} 2.5 \mathrm{mg} / \mathrm{kg}$; 9 th group: istradefylline $0.5 \mathrm{mg} / \mathrm{kg}+\mathrm{Zn}^{2+} 2.5 \mathrm{mg} / \mathrm{kg}$.

\subsection{Behavioural Studies}

\subsubsection{Forced Swim Test (FST)}

The FST procedure was conducted according to the method described by Porsolt et al. [60]. Each animal was placed singly into the glass cylinders (height $25 \mathrm{~cm}$, diameter $10 \mathrm{~cm}$ ) containing $10 \mathrm{~cm}$ of water at $23-25^{\circ} \mathrm{C}$ for $6 \mathrm{~min}$. Since slight immobility was observed during the first $2 \mathrm{~min}$, the total duration of immobility was recorded between the 2nd and the 6th min of the experiment. The animal was considered immobile when it stopped struggling and remained motionless, making only the movements indispensable to keep head above the water.

The results obtained in the FST were presented as the arithmetic mean of immobility time of mice in $\mathrm{s} \pm$ standard error of the mean (SEM) for each group. 


\subsubsection{Tail Suspension Test (TST)}

The TST procedure was conducted according to the method described by Steru et al. [39]. Each animal was suspended singly by the tail using adhesive tape for $6 \mathrm{~min}$. Since slight immobility was observed during the first $2 \mathrm{~min}$, the total duration of immobility was recorded between the 2 nd and the 6 th min of the experiment. The animal was considered immobile when it stopped struggling and ceased moving limbs and body, making only the movements indispensable to breathe.

The results obtained in the TST were presented as the arithmetic mean of immobility time of mice in $\mathrm{s} \pm$ standard error of the mean (SEM) for each group.

\subsubsection{Spontaneous Locomotor Motility}

The spontaneous locomotor motility was assessed using an Opto-Varimex-4 AutoTrack (Columbus Instruments, USA). The actimeter consists of four transparent cages $(43 \times 43 \times 32 \mathrm{~cm})$ covered with lids, a set of four infrared emitters, with 16 laser beams each, and four detectors tracking and monitoring mice movements. After administration of respective drug/drug combinations each animal was placed individually into the cages for $6 \mathrm{~min}$. Spontaneous locomotor motility was analysed between the 2nd and the 6th min of the experiment, which corresponds with the time interval evaluated in the FST and TST.

The results obtained in the spontaneous locomotor motility test were presented as the arithmetic average distance travelled (in $\mathrm{cm}$ ) by animals \pm SEM for each group.

\subsection{Biochemical and Molecular Studies}

\subsubsection{BDNF Levels Analysis}

(1) Collection of Blood

After the behavioural tests, the mice were decapitated by experienced animal technicians with the appropriate certificates. The murine blood was collected into Eppendorf tubes and allowed to clot at room temperature. Then, the blood was centrifuged for $10 \mathrm{~min}$ at $5000 \times g$ and serum was collected into polyethylene tubes and frozen at $-25^{\circ} \mathrm{C}$.

\section{(2) Determination of BDNF Concentration}

The concentration of BDNF in murine serum was measured by a ready-to-use sandwich enzyme immunoassay (ELISA) diagnostic kit dedicated to mouse fluids and tissues (Enzyme-linked Immunosorbent Assay Kit For BDNF, Cloud-Clone Corp., Katy, TX, USA). All procedures were conducted according to the manufacturer's instructions.

\subsubsection{Gene Expression Analysis}

(1) Collection of Prefrontal Cortex

After the behavioural tests, the mice were decapitated by an experienced animal technicians with the appropriate certificates. The brain of mice was carefully removed immediately after the decapitation and immersed in cooled $\left(2-8^{\circ} \mathrm{C}\right)$ saline to remove blood. The prefrontal cortex was isolated and washed with $20 \mu \mathrm{L}$ injection solution and stored in a freezer at $-80^{\circ} \mathrm{C}$ for biochemical and molecular studies.

\section{(2) RNA Isolation}

Total RNA was isolated from $30 \mathrm{mg}$ of murine prefrontal cortex using TRIzol Reagent (Invitrogen, Carlsbad, CA, USA) according to the manufacturer's instructions. Briefly, $500 \mu \mathrm{L}$ of TRIzol reagent was added to the tissue and homogenized using a homogenizer. Then, $100 \mu \mathrm{L}$ of chloroform (POCH, Gliwice, Poland) was added, and the mixture was incubated for $3 \mathrm{~min}$ and centrifuged $\left(15 \mathrm{~min}, 12,000 \times g, 4{ }^{\circ} \mathrm{C}\right)$. The colourless aqueous phase containing RNA was transferred to a new tube and $250 \mu \mathrm{L}$ of isopropanol $(\mathrm{POCH}$, Gliwice, Poland) was added. The obtained mixture was incubated for $10 \mathrm{~min}$ and then centrifuged $\left(10 \mathrm{~min}, 12,000 \times \mathrm{g}, 4^{\circ} \mathrm{C}\right)$. The formed white pellet at a bottom of the tube was washed with $500 \mu \mathrm{L}$ of $75 \%$ ethanol (POCH, Gliwice, Poland), dried and dissolved in $50 \mu \mathrm{L}$ of RNAse-free water (EURx, Gdańsk, Poland). 
The concentration and purity of RNA were measured spectrophotometrically using a NanoDrop Maestro Nano spectrophotometer (Maestrogen, Hsinchu, Taiwan). High purity RNA was used for further investigations (A260/280 ratio ranged between 1.8 and 2.0).

(3) cDNA Synthesis

Synthesis of cDNA was performed using a high-capacity cDNA reverse transcription kit (Applied Biosystems, Foster City, CA, USA) according to the manufacturer's procedure. Briefly, the following reaction mixture was prepared in triplicates: $2 \mu \mathrm{L}$ of 10X RT Buffer, $0.8 \mu \mathrm{L}$ of $25 \mathrm{X} \mathrm{dNTP}$ Mix $(100 \mathrm{mM}), 2 \mu \mathrm{L}$ of 10X RT random primers, $1 \mu \mathrm{L}$ of MultiScribe reverse transcriptase $(50 \mathrm{U} / \mu \mathrm{L}), 0.5 \mu \mathrm{L}$ of RNase inhibitor $(40 \mathrm{U} / \mu \mathrm{L}), 10 \mu \mathrm{L}$ of isolated RNA $(200 \mathrm{ng} / \mu \mathrm{L})$ and $3.2 \mu \mathrm{L}$ of RNase-free water.

The reaction conditions: $25^{\circ} \mathrm{C}$ for $10 \mathrm{~min}, 37^{\circ} \mathrm{C}$ for $120 \mathrm{~min}$, and then at $85^{\circ} \mathrm{C}$ for $5 \mathrm{~min}$ to complete the process. Received cDNA was stored at $-20^{\circ} \mathrm{C}$.

(4) Real-Time PCR

The relative expression of following genes was measured: Ogg1, Msra, Nfe2l2, Adora1, Comt and Slc6a15 by real-time PCR reaction, $\Delta \Delta \mathrm{Ct}$ method, using Hprt and Tbp as endogenous controls. The reaction was conducted in triplicate using the 7500 Fast Real-Time PCR System (Applied Biosystems, Foster City, CA, USA) and Fast Probe qPCR Master Mix $(2 \times)$, plus ROX Solution (EURx, Gdańsk, Poland). Briefly, reaction mixture contained $10 \mu \mathrm{L}$ of Fast Probe qPCR Master Mix $(2 \times), 9 \mu \mathrm{L}$ of RNase-free water, $0.5 \mu \mathrm{L}$ of ROX Solution (50 nM), and $0.5 \mu \mathrm{M}$ of gene-specific TaqMan probe (Applied Biosystems, Foster City, CA, USA) described in Table 2. The reactions was performed as followed: $95^{\circ} \mathrm{C}$ for $3 \mathrm{~min}$, 40 cycles: $95^{\circ} \mathrm{C}$ for $10 \mathrm{~s}$ and $60^{\circ} \mathrm{C}$ for $30 \mathrm{~s}$. The data quality screen based on amplification, $\mathrm{Tm}$ and $\mathrm{Ct}$ values was performed to remove any outlier data before $\Delta \Delta \mathrm{Ct}$ calculations and to determine fold change in mRNA levels. The outcomes were shown as RQ value $\left(\mathrm{RQ}=2^{-\Delta \Delta \mathrm{Ct}}\right)$.

Table 2. Gene symbols, gene names, GenBank reference sequence accession numbers, assay IDs and amplicon lengths (bp).

\begin{tabular}{|c|c|c|c|c|}
\hline Gene Symbol & Gene Name & Ref. Seq & Assay ID & Amplicon Length \\
\hline Ogg1 & $\begin{array}{c}\text { 8-Oxoguanine } \\
\text { DNA-glycosylase } 1\end{array}$ & NM_010957.4 & Mm00501784_m1 & 90 \\
\hline Msra & $\begin{array}{l}\text { Methionine sulfoxide } \\
\text { reductase A }\end{array}$ & $\begin{array}{l}\text { NM_001253712.1 } \\
\text { NM_001253714.1 } \\
\text { NM_001253716.1 } \\
\text { NM_026322.4 }\end{array}$ & Mm00452737_m1 & 69 \\
\hline$N f e 2 l 2$ & $\begin{array}{c}\text { Nuclear factor, } \\
\text { erythroid derived 2, like } 2\end{array}$ & NM_010902.3 & Mm00477784_m1 & 61 \\
\hline Adora1 & Adenosine A1 receptor & $\begin{array}{l}\text { NM_001008533.3 } \\
\text { NM_001039510.2 } \\
\text { NM_001282945.1 }\end{array}$ & Mm01308023_m1 & 58 \\
\hline Slc6a15 & $\begin{array}{l}\text { Solute carrier family } 6 \\
\text { (neurotransmitter } \\
\text { transporter), member } 15\end{array}$ & $\begin{array}{l}\text { NM_001252330.1 } \\
\text { NM_175328.3 }\end{array}$ & Mm00558415_m1 & 84 \\
\hline Comt & $\begin{array}{l}\text { Catechol-O-methyl- } \\
\text { transferase }\end{array}$ & $\begin{array}{l}\text { NM_001111062.1 } \\
\text { NM_001111063.1 } \\
\text { NM_007744.3 }\end{array}$ & Mm00514377_m1 & 97 \\
\hline Hprt & $\begin{array}{l}\text { Hypoxanthine guanine } \\
\text { phosphoribosyl transferase }\end{array}$ & NM_013556.2 & Mm00446968_m1 & 65 \\
\hline Tbp & $\begin{array}{c}\text { TATA box } \\
\text { binding protein }\end{array}$ & NM_013684.3 & Mm00446974_m1 & 105 \\
\hline
\end{tabular}




\subsection{Statistical Analysis}

A two-way ANOVA followed by a Bonferroni's post hoc test was used to analyse the results of the behavioural, biochemical and molecular studies and to determine interactions occurring between tested drugs when administered jointly. The differences between groups were considered statistically significant when $p<0.05$.

\section{Conclusions}

Summarizing, outcomes introduced in this research clearly show positive interaction of selective $\mathrm{A} 1$ and $\mathrm{A} 2 \mathrm{~A}$ adenosine receptor antagonists with $\mathrm{Mg}^{2+}$ and $\mathrm{Zn}^{2+}$, manifested as an antidepressant-like effect in the FST and TST without any stimulation of the animals' locomotor activity. This may indicate an interrelationship between adenosine and glutamatergic system, which could be responsible for the observed antidepressant activity during behavioural examination. In connection to the behavioural tests the biochemical results are surprising, because reducing the BDNF level in murine serum after co-administration of both selective antagonists of $\mathrm{A} 1$ and $\mathrm{A} 2 \mathrm{~A}$ receptors with the potent ion antagonists of the NMDA receptor complex was noted. Therefore, further research is needed to confirm and explain these changes. Additionally, molecular studies showed that (1) the pre-treatment with $\mathrm{Mg}^{2+}$ or $\mathrm{Zn}^{2+}$, both alone and in the combination with DPCPX as well as with istradefylline causes changes in A1 receptor expression, (2) co-administration of DPCPX with $\mathrm{Zn}^{2+}$ and istradefylline with $\mathrm{Zn}^{2+}$ results in an increase the mRNA level of Slc6a15 as compared to the single-drug administration, and (3) co-administration of tested agents does not have a more favourable effect on the Comt gene expression. Moreover, the changes obtained in the expression of selected antioxidant defence genes indicate that joint treatment with DPCPX- $\mathrm{Mg}^{2+}$, DPCPX- $-\mathrm{Zn}^{2+}$, istradefylline- $\mathrm{Mg}^{2+}$ and istradefylline- $\mathrm{Zn}^{2+}$ may have a more antioxidant capacity benefits than administration of DPCPX and istradefylline alone. These mechanisms might be responsible for the observed profitable effect of such concomitant treatment in mice despair tests. It seems plausible that a combination of selective A1 as well as A2A receptor antagonist and magnesium or zinc may be a new strategy to be used in the treatment of patients suffering from depressive disorders.

Author Contributions: Conceptualization: A.S. (Aleksandra Szopa), M.H., J.D., P.W. and E.P.; methodology: A.S. (Aleksandra Szopa), M.H., A.S. (Anna Serefko) and B.S.; formal analysis: A.S. (Aleksandra Szopa), K.B. and M.H.; investigation: K.B., M.O., S.W., K.Ś., A.P. and A.K.; resources: A.W., J.D. and E.P.; data curation: A.S. (Aleksandra Szopa) and M.H.; writing-original draft preparation: A.S. (Aleksandra Szopa), K.B. and M.H.; writing-review and editing: A.S. (Anna Serefko), M.O., S.W., K.Ś., B.S., A.W., P.S., A.W., S.M., A.P., A.K., J.D., M.R.-Z., P.W. and E.P.; visualization: K.B., A.W., P.S., S.M., M.R.-Z.; supervision: J.D. and E.P.; project administration: A.S. (Aleksandra Szopa) and M.H.; funding acquisition: E.P. All authors have read and agreed to the published version of the manuscript.

Funding: This research was funded by the Statutory Activity of Medical University of Lublin, Poland, grant number DS48.

Institutional Review Board Statement: All experimental procedures were prepared and carried out in accordance with the European Communities Council Directive of 22 September 2010 (2010/63/EU) and Polish legislation acts concerning animal experimentations. The protocols and procedures used in the research were accepted by the Ethics Committee in Lublin (license number 26/2019).

Informed Consent Statement: Not applicable.

Acknowledgments: The authors wish to thank Chair and Department of Hygiene of Medical University in Lublin for access to an animal activity meter Opto-Varimex-4 Auto-Track.

Conflicts of Interest: The authors declare no conflict of interest. 


\section{References}

1. Takeda, A. Movement of zinc and its functional significance in the brain. Brain Res. Rev. 2000, 34, 137-148. [CrossRef]

2. Eby, G.A.; Eby, K.L.; Murk, H. Magnesium and major depression. In Magnesium in the Central Nervous System; Vink, R., Nechifor, M., Eds.; University of Adelaide Press: Adelaide, Australia, 2011; pp. 313-330.

3. Sandstead, H.H. Subclinical zinc deficiency impairs human brain function. J. Trace Elem Med. Biol. 2012, 26, 70-73. [CrossRef] [PubMed]

4. Cieślik, K.; Klenk-Majewska, B.; Danilczuk, Z.; Wróbel, A.; Łupina, T.; Ossowska, G. Influence of zinc supplementation on imipramine effect in a chronic unpredictable stress (CUS) model in rats. Pharmacol. Rep. 2007, 59, 46-52. [PubMed]

5. Cunha, M.P.; Machado, D.G.; Bettio, L.E.; Capra, J.C.; Rodrigues, A.L. Interaction of zinc with antidepressants in the tail suspension test. Prog. Neuro-Psychopharmacol. Biol. Psychiatry 2008, 32, 1913-1920. [CrossRef] [PubMed]

6. Młyniec, K. Zinc in the glutamatergic theory of depression. Curr. Neuropharmacol. 2015, 13, 505-513. [CrossRef]

7. Salari, S.; Khomand, P.; Arasteh, M.; Yousefzamani, B.; Hassanzadeh, K. Zinc sulphate: A reasonable choice for depression management in patients with multiple sclerosis: A randomized, double-blind, placebo-controlled clinical trial. Pharmacol. Rep. 2015, 67, 606-609. [CrossRef] [PubMed]

8. Szewczyk, B.; Pochwat, B.; Rafało, A.; Palucha-Poniewiera, A.; Domin, H.; Nowak, G. Activation of mTOR dependent signaling pathway is a necessary mechanism of antidepressant-like activity of zinc. Neuropharmacology 2015, 99, 517-526. [CrossRef] [PubMed]

9. Poleszak, E.; Wlaź, P.; Kędzierska, E.; Nieoczym, D.; Wyska, E.; Szymura-Oleksiak, J.; Fidecka, S.; Radziwoń-Zaleska, M.; Nowak, G. Immobility stress induces depression-like behavior in the forced swim test in mice: Effect of magnesium and imipramine. Pharmacol. Rep. 2006, 58, 746-752.

10. Poleszak, E.; Wlaź, P.; Szewczyk, B.; Kędzierska, E.; Wyska, E.; Librowski, T.; Szymura-Oleksiak, J.; Fidecka, S.; Pilc, A.; Nowak, G. Enhancement of antidepressant-like activity by joint administration of imipramine and magnesium in the forced swim test: Behavioral and pharmacokinetic studies in mice. Pharmacol. Biochem. Behav. 2005, 81, 524-529. [CrossRef] [PubMed]

11. Whittle, N.; Lubec, G.; Singewald, N. Zinc deficiency induces enhanced depression-like behaviour and altered limbic activation reversed by antidepressant treatment in mice. Amino Acids 2009, 36, 147-158. [CrossRef]

12. Szewczyk, B.; Poleszak, E.; Wlaź, P.; Wróbel, A.; Blicharska, E.; Cichy, A.; Dybała, M.; Siwek, A.; Pomierny-Chamioło, L.; Piotrowska, A.; et al. The involvement of serotonergic system in the antidepressant effect of zinc in the forced swim test. Prog. Neuro-Psychopharmacol. Biol. Psychiatry 2009, 33, 323-329. [CrossRef] [PubMed]

13. Besser, L.; Chorin, E.; Sekler, I.; Silverman, W.F.; Atkin, S.; Russell, J.T.; Hershfinkel, M. Synaptically released zinc triggers metabotropic signaling via a zinc-sensing receptor in the hippocampus. J. Neurosci. 2009, 29, 2890-2901. [CrossRef]

14. Poleszak, E.; Wlaź, P.; Kędzierska, E.; Nieoczym, D.; Wróbel, A.; Fidecka, S.; Pilc, A.; Nowak, G. NMDA/glutamate mechanism of antidepressant-like action of magnesium in forced swim test in mice. Pharmacol. Biochem. Behav. 2007, 88, 158-164. [CrossRef]

15. Doboszewska, U.; Wlaź, P.; Nowak, G.; Radziwoń-Zaleska, M.; Cui, R.; Młyniec, K. Zinc in the monoaminergic theory of depression: Its relationship to neural plasticity. Neural Plast. 2017, 2017, 3682752. [CrossRef]

16. Paoletti, P.; Vergnano, A.M.; Barbour, B.; Casado, M. Zinc at glutamatergic synapses. Neuroscience 2009, 158, 126-136. [CrossRef]

17. Szewczyk, B.; Kubera, M.; Nowak, G. The role of zinc in neurodegenerative inflammatory pathways in depression. Prog. Neuro-Psychopharmacol. Biol. Psychiatry 2011, 35, 693-701. [CrossRef]

18. Fuxe, K.; Dahlström, A.B.; Jonsson, G.; Marcellino, D.; Guescini, M.; Dam, M.; Manger, P.; Agnati, L. The discovery of central monoamine neurons gave volume transmission to the wired brain. Prog. Neurobiol. 2010, 90, 82-100. [CrossRef] [PubMed]

19. Fredholm, B.B.; IJzerman, A.P.; Jacobson, K.A.; Linden, J.; Müller, C.E. International Union of Basic and Clinical Pharmacology. LXXXI. Nomenclature and classification of adenosine receptors-An update. Pharmacol. Rev. 2011, 63, 1-34. [CrossRef]

20. Borroto-Escuela, D.O.; Fuxe, K. Adenosine heteroreceptor complexes in the basal ganglia are implicated in Parkinson's disease and its treatment. J. Neural Transm. 2019, 126, 455-471. [CrossRef]

21. Gomes, C.V.; Kaster, M.P.; Tomé, A.R.; Agostinho, P.M.; Cunha, R.A. Adenosine receptors and brain diseases: Neuroprotection and neurodegeneration. Biochim. Biophys. Acta 2011, 1808, 1380-1399. [CrossRef] [PubMed]

22. Ciruela, F.; Casadó, V.; Rodrigues, R.J.; Luján, R.; Burgueño, J.; Canals, M.; Borycz, J.; Rebola, N.; Goldberg, S.R.; Mallol, J.; et al. Presynaptic control of striatal glutamatergic neurotransmission by adenosine A1-A2A receptor heteromers. J. Neurosci. 2006, 26, 2080-2087. [CrossRef]

23. Fredholm, B.B.; Chen, J.F.; Cunha, R.A.; Svenningsson, P.; Vaugeois, J.M. Adenosine and brain function. Int. Rev. Neurobiol. 2005, 63, 191-270.

24. Wardas, J. Neuroprotective role of adenosine in the CNS. Pol. J. Pharmacol. 2002, 54, 313-326. [PubMed]

25. Brand, A.; Vissiennon, Z.; Eschke, D.; Nieber, K. Adenosine A(1) and A(3) receptors mediate inhibition of synaptic transmission in rat cortical neurons. Neuropharmacology 2001, 40, 85-95. [CrossRef]

26. Scammell, T.E.; Arrigoni, E.; Thompson, M.A.; Ronan, P.J.; Saper, C.B.; Greene, R.W. Focal deletion of the adenosine A1 receptor in adult mice using an adeno-associated viral vector. J. Neurosci. 2003, 23, 5762-5770. [CrossRef] [PubMed]

27. Schotanus, S.M.; Fredholm, B.B.; Chergui, K. NMDA depresses glutamatergic synaptic transmission in the striatum through the activation of adenosine A1 receptors: Evidence from knockout mice. Neuropharmacology 2006, 51, 272-282. [CrossRef]

28. Franco, R. Neurotransmitter receptor heteromers in neurodegenerative diseases and neural plasticity. J. Neural Transm. 2009, 116, 983-987. [CrossRef] 
29. Szopa, A.; Poleszak, E.; Wyska, E.; Serefko, A.; Wośko, S.; Wlaź, A.; Pieróg, M.; Wróbel, A.; Wlaź, P. Caffeine enhances the antidepressant-like activity of common antidepressant drugs in the forced swim test in mice. Naunyn Schmiedebergs Arch. Pharmacol. 2016, 389, 211-221. [CrossRef] [PubMed]

30. Serefko, A.; Szopa, A.; Wlaź, A.; Wośko, S.; Wlaź, P.; Poleszak, E. Synergistic antidepressant-like effect of the joint administration of caffeine and NMDA receptor ligands in the forced swim test in mice. J. Neural Transm. 2016, 123, 463-472. [CrossRef]

31. Szopa, A.; Poleszak, E.; Bogatko, K.; Wyska, E.; Wośko, S.; Doboszewska, U.; Świąder, K.; Wlaź, A.; Dudka, J.; Wróbel, A.; et al . DPCPX, a selective adenosine A1 receptor antagonist, enhances the antidepressant-like effects of imipramine, escitalopram, and reboxetine in mice behavioral tests. Naunyn Schmiedebergs Arch. Pharmacol. 2018, 391, 1361-1371. [CrossRef]

32. Poleszak, E.; Szopa, A.; Bogatko, K.; Wyska, E.; Wośko, S.; Świąder, K.; Doboszewska, U.; Wlaź, A.; Wróbel, A.; Wlaź, P.; et al. Antidepressant-like activity of typical antidepressant drugs in the forced swim test and tail suspension test in mice is augmented by DMPX, an adenosine A(2A) receptor antagonist. Neurotox. Res. 2019, 35, 344-352. [CrossRef]

33. Herbet, M.; Szopa, A.; Serefko, A.; Wośko, S.; Gawrońska-Grzywacz, M.; Izdebska, M.; Piątkowska-Chmiel, I.; Betiuk, P.; Poleszak, E.; Dudka, J. 8-Cyclopentyl-1,3-dimethylxanthine enhances effectiveness of antidepressant in behavioral tests and modulates redox balance in the cerebral cortex of mice. Saudi Pharm. J. 2018, 26, 694-702. [CrossRef] [PubMed]

34. Cryan, J.F.; Mombereau, C.; Vassout, A. The tail suspension test as a model for assessing antidepressant activity: Review of pharmacological and genetic studies in mice. Neurosci. Biobehav. Rev. 2005, 29, 571-625. [CrossRef] [PubMed]

35. Petit-Demouliere, B.; Chenu, F.; Bourin, M. Forced swimming test in mice: A review of antidepressant activity. Psychopharmacology 2005, 177, 245-255. [CrossRef]

36. Bai, F.; Li, X.; Clay, M.; Lindstrom, T.; Skolnick, P. Intra- and interstrain differences in models of "behavioral despair". Pharmacol. Biochem. Behav. 2001, 70, 187-192. [CrossRef]

37. Porsolt, R.D.; Lenegre, A. Behavioral models of depression. In Experimental Approaches to Anxiety and Depression; Elliot, J.M., Heal, D.J., Marsden, C.A., Eds.; John Wiley \& Sons: London, UK, 1992; pp. 73-85.

38. Dalvi, A.; Lucki, I. Murine models of depression. Psychopharmacology 1999, 147, 14-16. [CrossRef]

39. Steru, L.; Chermat, R.; Thierry, B.; Simon, P. The tail suspension test: A new method for screening antidepressants in mice. Psychopharmacology 1985, 85, 367-370. [CrossRef] [PubMed]

40. Maj, J.; Rogóż, Z.; Skuza, G.; Sowińska, H. Effects of MK-801 and antidepressant drugs in the forced swimming test in rats. Eur. Neuropsychopharmacol. 1992, 2, 37-41. [CrossRef]

41. Trullas, R.; Skolnick, P. Functional antagonists at the NMDA receptor complex exhibit antidepressant actions. Eur. J. Pharmacol 1990, 185, 1-10. [CrossRef]

42. Li, X.; Tizzano, J.P.; Griffey, K.; Clay, M.; Lindstrom, T.; Skolnick, P. Antidepressant-like actions of an AMPA receptor potentiator (LY392098). Neuropharmacology 2001, 40, 1028-1033. [CrossRef]

43. Fredholm, B.B.; Chen, J.F.; Masino, S.A.; Vaugeois, J.M. Actions of adenosine at its receptors in the CNS: Insights from knockouts and drugs. Annu Rev. Pharmacol. Toxicol. 2005, 45, 385-412. [CrossRef] [PubMed]

44. Górska, A.M.; Gołembiowska, K. The role of adenosine A1 and A2A receptors in the caffeine effect on MDMA-induced DA and 5-HT release in the mouse striatum. Neurotox. Res. 2015, 27, 229-245. [CrossRef]

45. Sperlágh, B.; Vizi, E.S. The role of extracellular adenosine in chemical neurotransmission in the hippocampus and Basal Ganglia: Pharmacological and clinical aspects. Curr. Top. Med. Chem. 2011, 11, 1034-1046. [CrossRef]

46. Blum, D.; Galas, M.C.; Pintor, A.; Brouillet, E.; Ledent, C.; Müller, C.E.; Bantubungi, K.; Galluzzo, M.; Gall, D.; Cuvelier, L.; et al. A dual role of adenosine A2A receptors in 3-nitropropionic acid-induced striatal lesions: Implications for the neuroprotective potential of A2A antagonists. J. Neurosci. 2003, 23, 5361. [CrossRef] [PubMed]

47. Corsi, C.; Pinna, A.; Gianfriddo, M.; Melani, A.; Morelli, M.; Pedata, F. Adenosine A2A receptor antagonism increases striatal glutamate outflow in dopamine-denervated rats. Eur. J. Pharmacol. 2003, 464, 33-38. [CrossRef]

48. Karcz-Kubicha, M.; Quarta, D.; Hope, B.T.; Antoniou, K.; Müller, C.E.; Morales, M.; Schindler, C.W.; Goldberg, S.R.; Ferré, S. Enabling role of adenosine A1 receptors in adenosine A2A receptor-mediated striatal expression of c-fos. Eur. J. Neurosci. 2003, 18, 296-302. [CrossRef]

49. Pintor, A.; Quarta, D.; Pezzola, A.; Reggio, R.; Popoli, P. SCH 58261 (an adenosine A(2A) receptor antagonist) reduces, only at low doses, K(+)-evoked glutamate release in the striatum. Eur. J. Pharmacol 2001, 421, 177-180. [CrossRef]

50. Quarta, D.; Ferré, S.; Solinas, M.; You, Z.B.; Hockemeyer, J.; Popoli, P.; Goldberg, S.R. Opposite modulatory roles for adenosine A1 and $\mathrm{A} 2 \mathrm{~A}$ receptors on glutamate and dopamine release in the shell of the nucleus accumbens. Effects of chronic caffeine exposure. J. Neurochem 2004, 88, 1151-1158. [CrossRef] [PubMed]

51. Solinas, M.; Ferré, S.; You, Z.B.; Karcz-Kubicha, M.; Popoli, P.; Goldberg, S.R. Caffeine induces dopamine and glutamate release in the shell of the nucleus accumbens. J. Neurosci. 2002, 22, 6321-6324. [CrossRef] [PubMed]

52. Borroto-Escuela, D.O.; Hinz, S.; Navarro, G.; Franco, R.; MĂL'ller, C.E.; Fuxe, K. Understanding the Role of Adenosine A2AR Heteroreceptor Complexes in Neurodegeneration and Neuroinflammation. Front. Neurosci. 2018, 12, 43. [CrossRef]

53. Bespalov, A.; Dravolina, O.; Belozertseva, I.; Adamcio, B.; Zvartau, E. Lowered brain stimulation reward thresholds in rats treated with a combination of caffeine and N-methyl-D-aspartate but not alpha-amino-3-hydroxy-5-methyl-4-isoxazole propionate or metabotropic glutamate receptor-5 receptor antagonists. Behav. Pharmacol. 2006, 17, 295-302. [CrossRef] 
54. de Oliveira, R.V.; Dall'Igna, O.P.; Tort, A.B.; Schuh, J.F.; Neto, P.F.; Santos Gomes, M.W.; Souza, D.O.; Lara, D.R. Effect of subchronic caffeine treatment on MK-801-induced changes in locomotion, cognition and ataxia in mice. Behav. Pharmacol. 2005, 16, 79-84. [CrossRef] [PubMed]

55. Lobato, K.R.; Binfaré, R.W.; Budni, J.; Rosa, A.O.; Santos, A.R.; Rodrigues, A.L. Involvement of the adenosine A1 and A2A receptors in the antidepressant-like effect of zinc in the forced swimming test. Prog. Neuro-Psychopharmacol. Biol. Psychiatry 2008, 32, 994-999. [CrossRef]

56. Kreiner, G.; Chmielarz, P.; Roman, A.; Nalepa, I. Gender differences in genetic mouse models evaluated for depressive-like and antidepressant behavior. Pharmacol. Rep. 2013, 65, 1580-1590. [CrossRef]

57. Liu, L.L.; Li, J.M.; Su, W.J.; Wang, B.; Jiang, C.L. Sex differences in depressive-like behaviour may relate to imbalance of microglia activation in the hippocampus. Brain Behav. Immun. 2019, 81, 188-197. [CrossRef] [PubMed]

58. McHenry, J.; Carrier, N.; Hull, E.; Kabbaj, M. Sex differences in anxiety and depression: Role of testosterone. Front. Neuroendocrinol. 2014, 35, 42-57. [CrossRef] [PubMed]

59. Kaster, M.P.; Rosa, A.O.; Rosso, M.M.; Goulart, E.C.; Santos, A.R.; Rodrigues, A.L. Adenosine administration produces an antidepressant-like effect in mice: Evidence for the involvement of A1 and A2A receptors. Neurosci. Lett. 2004, 355, 21-24. [CrossRef]

60. Porsolt, R.D.; Bertin, A.; Jalfre, M. Behavioral despair in mice: A primary screening test for antidepressants. Arch. Int. Pharmacodyn. Ther. 1977, 229, 327-336.

61. Browne, R.G.; Welch, W.M. Stereoselective antagonism of phencyclidine's discriminative properties by adenosine receptor agonists. Science 1982, 217, 1157-1159. [CrossRef]

62. Popoli, P.; Reggio, R.; Pezzola, A. Adenosine A1 and A2 receptor agonists significantly prevent the electroencephalographic effects induced by MK-801 in rats. Eur. J. Pharmacol. 1997, 333, 143-146. [CrossRef]

63. Craig, C.G.; White, T.D. N-methyl-D-aspartate- and non-N-methyl-D-aspartate-evoked adenosine release from rat cortical slices: Distinct purinergic sources and mechanisms of release. J. Neurochem. 1993, 60, 1073-1080. [CrossRef]

64. Manzoni, O.J.; Manabe, T.; Nicoll, R.A. Release of adenosine by activation of NMDA receptors in the hippocampus. Science 1994, 265, 2098-2101. [CrossRef] [PubMed]

65. Melani, A.; Corsi, C.; Giménez-Llort, L.; Martínez, E.; Ogren, S.O.; Pedata, F.; Ferré, S. Effect of N-methyl-D-aspartate on motor activity and in vivo adenosine striatal outflow in the rat. Eur. J. Pharmacol. 1999, 385, 15-19. [CrossRef]

66. Sebastiao, A.M.; Ribeiro, J.A. Fine-tuning neuromodulation by adenosine. Trends Pharmacol. Sci. 2000, 21, 341-346. [CrossRef]

67. Yu, H.; Chen, Z.Y. The role of BDNF in depression on the basis of its location in the neural circuitry. Acta Pharmacol. Sin. 2011, 32, 3-11. [CrossRef]

68. Duman, R.S.; Malberg, J.; Nakagawa, S.; D’Sa, C. Neuronal plasticity and survival in mood disorders. Biol. Psychiatry 2000, 48, 732-739. [CrossRef]

69. Altar, C.A. Neurotrophins and depression. Trends Pharmacol. Sci. 1999, 20, 59-61. [CrossRef]

70. Orzelska-Górka, J.; Szewczyk, K.; Gawrońska-Grzywacz, M.; Kędzierska, E.; Głowacka, E.; Herbet, M.; Dudka, J.; Biała, G. Monoaminergic system is implicated in the antidepressant-like effect of hyperoside and protocatechuic acid isolated from Impatiens glandulifera Royle in mice. Neurochem. Int. 2019, 128, 206-214. [CrossRef]

71. Kozisek, M.E.; Middlemas, D.; Bylund, D.B. Brain-derived neurotrophic factor and its receptor tropomyosin-related kinase B in the mechanism of action of antidepressant therapies. Pharmacol. Ther. 2008, 117, 30-51. [CrossRef]

72. Hennigan, A.; Callaghan, C.K.; Kealy, J.; Rouine, J.; Kelly, A.M. Deficits in LTP and recognition memory in the genetically hypertensive rat are associated with decreased expression of neurotrophic factors and their receptors in the dentate gyrus. Behav. Brain Res. 2009, 197, 371-377. [CrossRef]

73. Paizanis, E.; Kelai, S.; Renoir, T.; Hamon, M.; Lanfumey, L. Life-long hippocampal neurogenesis: Environmental, pharmacological and neurochemical modulations. Neurochem. Res. 2007, 32, 1762-1771. [CrossRef]

74. Phillips, C. Brain-derived neurotrophic factor, depression, and physical activity: Making the neuroplastic connection. Neural Plast. 2017, 2017, 7260130. [CrossRef]

75. Duman, R.S.; Monteggia, L.M. A neurotrophic model for stress-related mood disorders. Biol. Psychiatry 2006, 59, 1116-1127. [CrossRef] [PubMed]

76. Autry, A.E.; Monteggia, L.M. Brain-derived neurotrophic factor and neuropsychiatric disorders. Pharmacol. Rev. 2012, 64, 238-258. [CrossRef]

77. Klein, A.B.; Williamson, R.; Santini, M.A.; Clemmensen, C.; Ettrup, A.; Rios, M.; Knudsen, G.M.; Aznar, S. Blood BDNF concentrations reflect brain-tissue BDNF levels across species. Int. J. Neuropsychopharmacol. 2011, 14, 347-353. [CrossRef] [PubMed]

78. Sartorius, A.; Hellweg, R.; Litzke, J.; Vogt, M.; Dormann, C.; Vollmayr, B.; Danker-Hopfe, H.; Gass, P. Correlations and discrepancies between serum and brain tissue levels of neurotrophins after electroconvulsive treatment in rats. Pharmacopsychiatry 2009, 42, 270-276. [CrossRef] [PubMed]

79. Gejl, A.K.; Enevold, C.; Bugge, A.; Andersen, M.S.; Nielsen, C.H.; Andersen, L.B. Associations between serum and plasma brain-derived neurotrophic factor and influence of storage time and centrifugation strategy. Sci. Rep. 2019, 9, 9655. [CrossRef] [PubMed] 
80. Karege, F.; Schwald, M.; Cisse, M. Postnatal developmental profile of brain-derived neurotrophic factor in rat brain and platelets. Neurosci. Lett. 2002, 328, 261-264. [CrossRef]

81. Russo-Neustadt, A.; Beard, R.C.; Cotman, C.W. Exercise, antidepressant medications, and enhanced brain derived neurotrophic factor expression. Neuropsychopharmacology 1999, 21, 679-682. [CrossRef]

82. Nibuya, M.; Morinobu, S.; Duman, R.S. Regulation of BDNF and trkB mRNA in rat brain by chronic electroconvulsive seizure and antidepressant drug treatments. J. Neurosci. 1995, 15, 7539-7547. [CrossRef] [PubMed]

83. Chang, W.H.; Lee, I.H.; Chi, M.H.; Lin, S.H.; Chen, K.C.; Chen, P.S.; Chiu, N.T.; Yao, W.J.; Yang, Y.K. Prefrontal cortex modulates the correlations between brain-derived neurotrophic factor level, serotonin, and the autonomic nervous system. Sci. Rep. 2018, 8, 2558. [CrossRef]

84. Serchov, T.; Clement, H.W.; Schwarz, M.K.; Iasevoli, F.; Tosh, D.K.; Idzko, M.; Jacobson, K.A.; de Bartolomeis, A.; Normann, C.; Biber, K.; et al. Increased signaling via adenosine A1 receptors, sleep deprivation, imipramine, and ketamine inhibit depressive-like behavior via induction of Homer1a. Neuron 2015, 87, 549-562. [CrossRef]

85. Choi, S.; Han, K.M.; Kang, J.; Won, E.; Chang, H.S.; Tae, W.S.; Son, K.R.; Kim, S.J.; Lee, M.S.; Ham, B.J. Effects of a polymorphism of the neuronal amino acid transporter SLC6A15 gene on structural integrity of white matter tracts in major depressive disorder. PLoS ONE 2016, 11, e0164301. [CrossRef] [PubMed]

86. Eisenhofer, G.; Kopin, I.J.; Goldstein, D.S. Catecholamine metabolism: A contemporary view with implications for physiology and medicine. Pharmacol. Rev. 2004, 56, 331-349. [CrossRef]

87. Coelho, J.E.; de Mendonça, A.; Ribeiro, J.A. Presynaptic inhibitory receptors mediate the depression of synaptic transmission upon hypoxia in rat hippocampal slices. Brain Res. 2000, 869, 158-165. [CrossRef]

88. Stone, T.W.; Newby, A.C.; Lloyd, H.G.E. Adenosine release. In Adenosine and Adenosine Receptors; Williams, M., Ed.; The Humana Press: Totowa, NJ, USA, 1990; pp. 173-223.

89. El Yacoubi, M.; Ledent, C.; Parmentier, M.; Bertorelli, R.; Ongini, E.; Costentin, J.; Vaugeois, J.M. Adenosine A2A receptor antagonists are potential antidepressants: Evidence based on pharmacology and A2A receptor knockout mice. Br. J. Pharmacol. 2001, 134, 68-77. [CrossRef] [PubMed]

90. Kohli, M.A.; Lucae, S.; Saemann, P.G.; Schmidt, M.V.; Demirkan, A.; Hek, K.; Czamara, D.; Alexander, M.; Salyakina, D.; Ripke, S.; et al. The neuronal transporter gene SLC6A15 confers risk to major depression. Neuron 2011, 70, 252-265. [CrossRef] [PubMed]

91. Santarelli, S.; Wagner, K.V.; Labermaier, C.; Uribe, A.; Dournes, C.; Balsevich, G.; Hartmann, J.; Masana, M.; Holsboer, F.; Chen, A.; et al. SLC6A15, a novel stress vulnerability candidate, modulates anxiety and depressive-like behavior: Involvement of the glutamatergic system. Stress 2016, 19, 83-90. [CrossRef]

92. Gogos, J.A.; Morgan, M.; Luine, V.; Santha, M.; Ogawa, S.; Pfaff, D.; Karayiorgou, M. Catechol-O-methyltransferase-deficient mice exhibit sexually dimorphic changes in catecholamine levels and behavior. Proc. Natl. Acad. Sci. USA 1998, 95, 9991-9996. [CrossRef]

93. Antypa, N.; Drago, A.; Serretti, A. The role of COMT gene variants in depression: Bridging neuropsychological, behavioral and clinical phenotypes. Neurosci. BioBehav. Rev. 2013, 37, 1597-1610. [CrossRef] [PubMed]

94. Fukae, J.; Takanashi, M.; Kubo, S.; Nishioka, K.; Nakabeppu, Y.; Mori, H.; Mizuno, Y.; Hattori, N. Expression of 8-oxoguanine DNA glycosylase (OGG1) in Parkinson's disease and related neurodegenerative disorders. Acta Neuropathol. 2005, 109, 256-262. [CrossRef] [PubMed]

95. Vaváková, M.; Ďuračková, Z.; Trebatická, J. Markers of oxidative stress and neuroprogression in depression disorder. Oxid. Med. Cell. Longev. 2015, 2015, 898393. [CrossRef]

96. Ceylan, D.; Yilmaz, S.; Tuna, G.; Kant, M.; Er, A.; Ildi, A.; Verim, B.; Akis, M.; Akan, P.; Islekel, H.; et al. Alterations in levels of 8-Oxo-2'-deoxyguanosine and 8-Oxoguanine DNA glycosylase 1 during a current episode and after remission in unipolar and bipolar depression. Psychoneuroendocrinology 2020, 114, 104600. [CrossRef]

97. Szebeni, A.; Szebeni, K.; DiPeri, T.P.; Johnson, L.A.; Stockmeier, C.A.; Crawford, J.D.; Chandley, M.J.; Hernandez, L.J.; Burgess, K.C.; Brown, R.W.; et al. Elevated DNA oxidation and DNA repair enzyme expression in brain white matter in major depressive disorder. Int. J. Neuropsychopharmacol. 2017, 20, 363-373. [CrossRef] [PubMed]

98. Moskovitz, J.; Bar-Noy, S.; Williams, W.M.; Requena, J.; Berlett, B.S.; Stadtman, E.R. Methionine sulfoxide reductase (MsrA) is a regulator of antioxidant defense and lifespan in mammals. Proc. Natl. Acad. Sci. USA 2001, 98, 12920-12925. [CrossRef]

99. Moskovitz, J.; Flescher, E.; Berlett, B.S.; Azare, J.; Poston, J.M.; Stadtman, E.R. Overexpression of peptide-methionine sulfoxide reductase in Saccharomyces cerevisiae and human T cells provides them with high resistance to oxidative stress. Proc. Natl. Acad. Sci. USA 1998, 95, 14071-14075. [CrossRef] [PubMed]

100. Nguyen, T.; Nioi, P.; Pickett, C.B. The Nrf2-antioxidant response element signaling pathway and its activation by oxidative stress. J. Biol. Chem. 2009, 284, 13291-13295. [CrossRef] [PubMed]

101. Tomobe, K.; Shinozuka, T.; Kuroiwa, M.; Nomura, Y. Age-related changes of Nrf2 and phosphorylated GSK-3b in a mouse model of accelerated aging (SAMP8). Arch. Gerontol. Geriatr. 2012, 54, e1-e7. [CrossRef] [PubMed]

102. Wu, X.Y.; Qu, L.Y.; Quan, K.; Jiang, Y.L.; Tang, X.W. Effect of tBHQ and sulforaphane on Nrf2-ARE signaling pathway of Caco 2 cells. Zhejiang Da Xue Xue Bao Yi Xue Ban 2010, 39, 17-23. [PubMed]

103. Haskew-Layton, R.E.; Payappilly, J.B.; Smirnova, N.A.; Ma, T.C.; Chan, K.K.; Murphy, T.H.; Guo, H.; Langley, B.; Sultana, R.; Butterfield, D.A.; et al. Controlled enzymatic production of astrocytic hydrogen peroxide protects neurons from oxidative stress via an Nrf2-independent pathway. Proc. Natl. Acad. Sci. USA 2010, 107, 17385-17390. [CrossRef] 
104. Kobayashi, M.; Yamamoto, M. Molecular mechanisms activating the Nrf2-Keap1 pathway of antioxidant gene regulation. Antioxid. Redox Signal. 2005, 7, 385-394. [CrossRef] [PubMed]

105. Yamada, K.; Kobayashi, M.; Mori, A.; Jenner, P.; Kanda, T. Antidepressant-like activity of the adenosine A(2A) receptor antagonist, istradefylline (KW-6002), in the forced swim test and the tail suspension test in rodents. Pharmacol. Biochem. Behav. 2013, 114-115, 23-30. [CrossRef] [PubMed] 